DOI: doi.org/10.18372/38230

UDC: 665.775

\title{
1.4 POLYMER MODIFIED BITUMEN
}

\author{
Serhiy Pyshyev, Volodymyr Gunka, Yuriy Prysiazhnyi
}

According to [1] in 2013 ten major bitumen producers are: USA - 19.365 mln.tons (18.9 \%); China - 17.938 (17.5); Russia - 6.193 (6.0); India - 6.193 (4.7); Canada - 4.335 (4.2); Iran - 3.896 (3.8); Japan - 3.659 (3.6); South Korea - 3.614 (3.5); Germany - 3.410 (3.3); Italy 3.104 (3.0). These countries account for $68.5 \%$ of world bitumen production. Ukraine occupies only 53 place $-0.123 \mathrm{mln}$.tons $(0.1 \%)$.

The largest exporters of bitumen are [2]: South Korea - 2.264 mln.tons (11.5\%); Iran 2.179 (11.1); Singapore - 2.178 (11.1); Canada - 1.778 (9.0); USA - 1.539 (7.8). Due to the deficit Ukraine actualy does not export bitumen.

The largest importers of bitumen are [3]: China - 3.225 mln.tons (19.8\%); USA - 1.641 (9.8); France - 1.193 (7.1); Saudi Arabia - 0.996 (5.9); Algeria - 0.729 (4.3). Ukraine imports 0.165 mln.tons $\left(1.0 \% ; 21^{\text {st }}\right.$ place in the world $)$.

World consumption of bitumen is on the average $87 \mathrm{mln}$.tons per year. The structure of consumption by world regions is shown in Fig. 1.

About $85 \%$ of petroleum bitumen are used as a binder in various types of asphalt laying: sidewalks, highways, airports, etc. (Fig. 1).
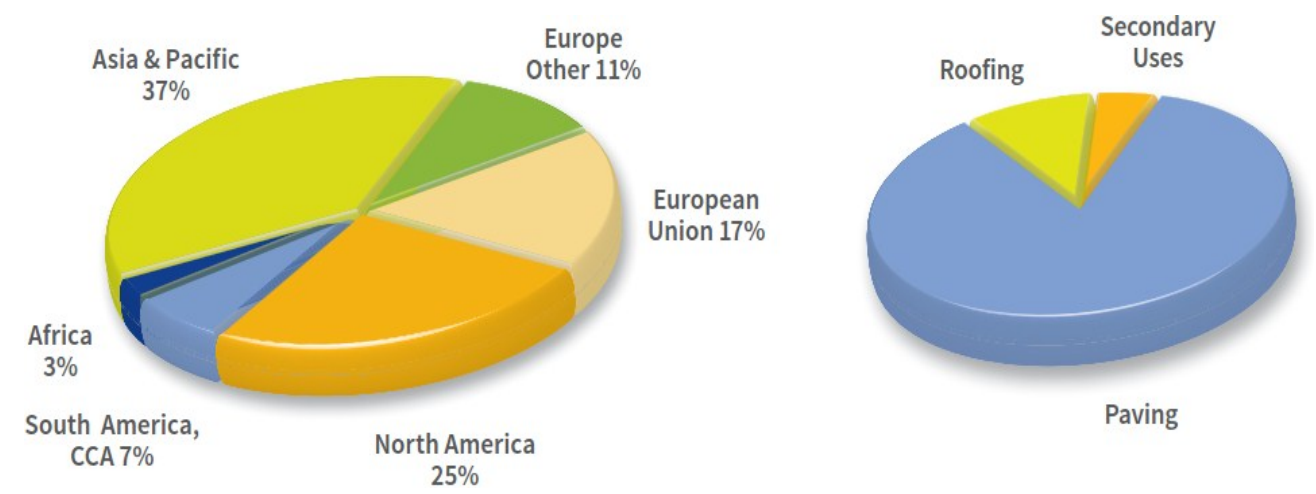

Fig. 1. World consumption of bitumen

To date bitumen-mineral mixtures for pavement are prepared by two ways: (i) as a result of bitumen heating to the temperatures exceeding their dropping points; (ii) by obtaining aqueous bituminous emulsions. Table 1 represents the composition of petroleum bitumen consumption by the road industry in Europe according to EAPA (European Asphalt Pavement Association).

When using bitumen for the production of asphalt mixtures it is not always possible to create a material that fully satisfied consumers by their performance properties. In particular, bitumen is generally characterized by poor adhesion, low temperature and plastic properties, leading to poor strength of the roadway. One of the ways of solving this problem is modification of commercial bitumen. Modified bitumen is characterized by improved flexibility and longer service life, it also has a lower brittleness temperature and higher softening temperature [4-7].

The share of modified bitumen, relative to its total use in road construction, is irregularly distributed between European countries, but as a rule, this share is above $10 \%$. The leaders are (\%): Romania - 75; Slovakia - 29.1; Belgium - 26.5; Hungary - 25; Czech - 21.5 (Table 1). 
Table 1

Consumption of bitumen in the road industry

\begin{tabular}{|c|c|c|c|c|c|c|}
\hline \multirow{2}{*}{ Country } & \multirow{2}{*}{$\begin{array}{l}\text { Tonnage in } \\
2014 \text {, mln. } t\end{array}$} & \multicolumn{4}{|c|}{ Percent of modified bitumen (of total) } & \multirow{2}{*}{$\begin{array}{l}\text { Emulsions in } \\
2014 \text {, mln. }\end{array}$} \\
\hline & & in 2011 & in 2012 & in 2013 & in 2014 & \\
\hline Austria & 0.37 & 25.0 & 25.0 & 30.0 & 18.9 & 0.005 \\
\hline Belgium & 0.21 & 25.5 & 27.0 & 25.4 & 26.5 & No data \\
\hline Croatia & 0.13 & No data & No data & No data & 10.00 & No data \\
\hline Czech Republic & 0.33 & 18.0 & 22.4 & 22.1 & 21.5 & 0.008 \\
\hline Denmark & 0.19 & 5.0 & 5.0 & 5.0 & 5.0 & 0.020 \\
\hline Estonia & 0.08 & No data & No data & 4.0 & 3.3 & 0.016 \\
\hline Finland & 0.27 & 0 & No data & 0 & 0 & 0.001 \\
\hline France & 2.47 & $<10$ & 13.0 & 13.0 & 6.9 & 0.792 \\
\hline Germany & 1.60 & No data & No data & No data & No data & No data \\
\hline Great Britain & 1.28 & 8.0 & 8.0 & 8.0 & 8.0 & 0.100 \\
\hline Greece & No data & 2.0 & 1.5 & 2.2 & No data & No data \\
\hline Hungary & 0.19 & 11.0 & 15.4 & 30.0 & 25.0 & 0 \\
\hline Iceland & No data & No data & No data & No data & 0 & 0 \\
\hline Ireland & 0.13 & No data & No data & No data & No data & 0 \\
\hline Italy & No data & 14.0 & 13.0 & 14.0 & No data & No data \\
\hline Lithuania & No data & 14.0 & 11.0 & No data & No data & No data \\
\hline Luxembourg & 0.05 & 20.0 & 30.0 & No data & 15.0 & No data \\
\hline Netherland & 0.30 & No data & No data & 5.0 & No data & No data \\
\hline Norway & 0.35 & 15.0 & No data & No data & No data & No data \\
\hline Poland & No data & 21.0 & 22.0 & 25.0 & No data & No data \\
\hline Romania & 0.20 & 74.0 & 45.0 & 76.0 & 75.0 & 0 \\
\hline Serbia & 0.26 & 14.7 & 6.0 & 4.2 & 4.4 & No data \\
\hline Slovakia & 0.08 & 60.0 & 37.0 & 31.0 & 29.1 & 0 \\
\hline Slovenia & 0.07 & 10.0 & 11.0 & 9.0 & 10.0 & No data \\
\hline Spain & 0.56 & 13.1 & 19.6 & 10.0 & 15.0 & 0 \\
\hline Sweden & 0.45 & 6.0 & 5.0 & No data & 7.0 & 0 \\
\hline Switzerland & 0.28 & 10.0 & 11.0 & 2.0 & 12.0 & 0 \\
\hline Turkey & 2.39 & 8.0 & 7.5 & 4.4 & 3.2 & 0.026 \\
\hline
\end{tabular}

As mentioned above, due to its natural properties petroleum bitumen is not able to create the conditions for long-term operation of pavement under modern heavy duty traffic and adverse weather factors.

Therefore, in addition to providing the required quality and durability it is necessary to radically improve the physical and mechanical characteristics of these materials by complex modification with additives.

From a technical point of view, to create a bitumen-based composite materials with a given set of properties only those substances may be applied, which meet the following requirements [14]:

- they are not destroyed at the temperature of asphalt-concrete mixture preparation;

- they are compatible with bitumen during the mixing process on conventional equipment at the temperatures usual for preparation of asphalt-concrete mixtures; 
- in summer they increase the stability of bitumen (which is a part of the roadway) to the deformation impact loads without increasing its viscosity at the temperatures of mixing and laying and do not impart brittleness to bitumen at low temperatures;

- they are chemically and physically stable and do not change their properties during transport, storage, processing and operating conditions of pavement.

According to their action the modifiers can be divided into adhesion, plasticizing, structuring and complex ones.

Adhesion additives significantly improve bitumen adhesion to stone materials and, as a rule, bitumen particles with each other, provide high water resistance of asphalt-concrete and prevent damage of the pavement. Adhesion additives also retard the bitumen aging [8,9].

Plasticizing additives provide modified bitumen with necessary consistency due to which they withstand deformation load and temperature changes [10].

Structuring additives can become cross-link binders and thereby provide the required strength of the roadway coating.

Complex additives are widely used in the road-building. They significantly improve the rheological properties of modified bitumen and their adhesion to mineral materials surface [11-14].

Additives for improving roadway quality are introduced into bitumen or directly into asphalt-concrete mixtures.

Additives which are introduced directly into bitumen can be divided into: polymer compounds, adhesive agents and specific components (e.g. sulfur). Additives introduced into asphalt-concrete mixtures are divided into: stabilizing (based on fibers), structuring (mineral powder, cement), structuring and stabilizing (natural bitumen, polymers, waxes).

Modification by polymer materials is one of the most perspective ways to improve the quality of binders to produce road surfaces with improved characteristics. The compounds used to produce polymer modified bitumen (PMB) are described below.

Polymer compounds, used as modifiers, may be assigned to one of four groups according to their nature, which implies a way to influence the properties of bitumen and method of introduction into PMB [4, 6, 13-14].

1) elastomers - natural and synthetic rubber, rubber crumb;

2) thermoplastic elastomers - block copolymers of butadiene and styrene type SBS;

3 ) thermosetting plastics - various copolymers and kooligomers (further - resins), which are usually have a large number of functional groups: epoxy, furfurol- and phenol-formaldehyde, carbamide, silicone, etc.

4) thermoplastics - polyvinyl acetate, polystyrene, polyisobutylene, polyethylene, polypropylene, atactic polypropylene, polyvinyl chloride, thermoplastics Elvaloy-4170 (copolymer of ethylene with butyl acrylate and glycidyl methacrylate), latexes of ButonalNS type, Viskoplast$\mathrm{S}$, ethylene methyl acrylate (EVA), petroleum resins.

By volumes of using the polymers are placed in the following order: thermoplastic elastomers of SBS type; thermoplastics of ethylene vinyl acetate type (EVA), polyisobutylene, polypropylene, a variety of block copolymers; polymer latexes and thermopolymers of ethylene glycidyl acrylate type $[6,7]$.

This type of modifiers includes polymers, rubbers and rubber polymers [6, 7, 15-21]. For the bitumen-polymer composition rubber imparts a new property - flexibility, which is typical of natural rubber in a wide temperature range. The new rheological state provides composition deformation at low temperatures, despite the lack of plastic properties of bitumen. In other words, this additive in bitumen improves its extensibility and elasticity at low temperatures, improves thermal and crack resistance, strength, deformation resistance, water resistance, frost resistance, durability, resistance to aging. 
Rubber can be introduced into bitumen by direct fusion, or in the presence of a solvent.

The example of most suitable for bitumen modification elastomers is synthetic rubbers of general purpose (isoprene, divinyl, divinyl styrene, ethylene propylene). These rubbers are produced as a briquetted solid elastic product which is used for gum production via rubber vulcanization.

The main disadvantage of elastomers is their poor dispersion in bitumen, so special measures are needed to obtain homogeneous modified bitumen (fusing, special solvents, etc.). Moreover, phase separation between polymer and bitumen in a liquid phase takes place, especially during storage. To avoid this phenomenon complicated devices that can support high temperatures and PMB continuous mixing are needed.

According to the published data $[20,21]$ rubber crumb is a promising product to be used for the modification. The main advantages are low cost and possibility of tires and other waste rubber products recycling. Despite the obvious advantages over other modifiers, using crumb rubber in road building is also limited because of the technological difficulties that arise when they are mixed with bitumen.

There are three types of styrene block copolymers: styrene-butadiene-styrene (SBS), styrene-isoprene-styrene (SIS), styrene-ethylene / butylene-styrene (SEBS). The content of polymers in PMB can reach 3-10 wt \%. Thermoplastic elastomers (TE), compared to thermoplastics, are characterized by higher elasticity, i.e. TE combine the strength of thermoplastics and elasticity of elastomers [4, 6, 7, 15-17, 22-24].

Styrene block copolymers of SBS type are mostly used for bitumen modification due to their ability to increase the strength of bitumen, and to provide polymer-bitumen compositions with elasticity, including that at low temperatures. Thermoplastic elastomer of SBS type is a linear polymer, which provides elasticity (ability to initial distortion) for bitumen-polymer system due to its structure (styrene units are linked by butadiene "flexible" blocks). TE retain the ability to highly elastic deformations within the temperature range of $193-353 \mathrm{~K}$. The temperature of TE destruction is $463-483 \mathrm{~K}$.

Block copolymers of butadiene and styrene of SBS type are well combine with bitumen because polystyrene and polybutadiene are swelled in paraffin-naphthenic and aromatic hydrocarbons of bitumen and partially dissolved in them at $423 \mathrm{~K}$.

To improve polymer dissolution in bitumen the plasticizers are used (usually a mixture of aromatic based hydrocarbons). Plasticizer significantly improves the polymer solubility in bitumen, but slightly decreases the adhesive properties of the resulting binder compared to the original bitumen $[4,7]$.

Due to their properties TE are produced in a variety of trademarks [25-28]: Kraton D1101, Kraton D1184, Kraton D1186 (Kraton Polimers, USA); Finaprene 411 (Total, France); Europrene Sol T 161B (Eni, Italy); Calprene 411 (Dynasol, Spain); DST 30-01 and DST-30R-01 (Voronezh factory, Russia).

The main disadvantage, restraining the growth of modified bitumen production is its high cost. Bitumen modified by TE is 1.5-2.5 times more expensive than unmodified bitumen [5].

Thermosetting plastics (TP) are polymers, which turn into solid state while heating or introducing hardener. Before hardening TP molecules have a linear structure, the same as thermoplastics molecules, but the size of their molecules is significantly smaller. TP molecules are chemically active. They contain either double (unsaturated) bonds or chemically active groups. Therefore, under certain conditions (at heating, irradiation or adding hardeners) thermosetting molecules react with each other and form a continuous network. Epoxy, phenol-formaldehyde, carbamide, polyester, silicone and other resins belong to TP [4, 6, 7, 29-33].

Bitumen-polymer binders with thermosetting plastics have relatively high adhesion to the mineral particles and high strength. 
The use of TP for bitumen-polymer mixtures create a number of disadvantages [4]:

- when entering hardener the technological properties of PMB are almost immediately deteriorated;

- rigidity is increased at low temperatures;

- the use of special hardeners complicates the system and raises its price;

- the effectiveness of thermosetting plastics appears usually at their large quantities in bitumen - more than $10 \mathrm{wt} \%$.

These polymer additives improve strength and deformation characteristics of bitumen and asphalt: the resistance to rutting at elevated temperatures increases, risk of cracking at low temperatures and fatigue cracking of asphalt under prolonged stress is reduced. Polymers which are quite often used now: polyvinyl acetate, polystyrene, polyisobutylene, polyethylene, polypropylene, atactic polypropylene, polypropylene, polyvinyl chloride, Viskoplast-S, EVA, ethylene methyl acrylate [4, 6, 7, 15, 27, 34-37]. However, the use of "traditional" polymers (polyethylene, polypropylene, etc.) is accompanied by a number of problems because rigidity and brittleness of resulting PMB increase after modification. As a result, a pavement using such binders, is disposed to increased cracking at low temperatures.

Synthetic latex of ButonalNS type (BASF, Germany) [38-41] and thermopolymers of Elvaloy series (DuPont, USA) [4, 15, 42] are widely used. These polymers not only reduce bitumen sensitivity to temperature changes, but also enhance the cohesive and adhesive strength resulting in the increase of strength and crack resistance of asphalt concrete pavement.

Petroleum resins obtained from by-products of fossil fuels thermodestruction occupy a special position among thermoplastics. They can be used to improve bitumen properties, namely they increase the viscosity, hardness, durability and adhesion to mineral materials [43-45]. The additives containing polar groups in their molecules, contribute to improved wettability of the mineral materials with bitumen, creating an adsorption and hemosorption monomolecular layers providing strong adhesion of bitumen-mineral mixture.

Petroleum resins with functional groups are of special attention. These compounds may belong both to thermoplastics and thermosetting plastics. The presence of functional groups in petroleum resin structure significantly improves the adhesion properties of bituminous materials, resulting in increased durability of the products based on them. The use of petroleum resins for bitumen modification is limited due to their considerable cost. Moreover, under high temperatures these compounds can form three-dimensional cross-linked structure with petroleum bitumen that reduces its plasticity. As a result cracking of asphalt pavement occurs. Under long-term exposure to high temperatures during preparation, transportation and laying of road surfaces thermal degradation of polymers is also possible, so they can lose modifying properties.

Resin modifiers may also be produced from coal processing secondary products. The investigations concerning using coumarone-indene resin (CIR) as a modifier were carried out at the Department of Oil and Gas Processing of Lviv Polytechnic National University [46-48]. CIR is a polymerization product of a mixture of compounds (mainly indene, coumarone and styrene), which are by-products of the coking process («heavy» benzene, coal tar light fractions).

Phenol-cresol-formaldehyderesinsare also high-effective modifiers of bitumen, the road bitumen first of all. Resins are producedviapolycondensationmethodfromphenolicfractionwhich is obtained from coal tar $[49,50]$.

Taking into account the high efficiency of above-mentioned modifiers, their relatively simple methods of production and low cost, the Section 3 is devoted to the application of resins in polymer modified bitumen production.

Other types of modifiers (non-polymer modifiers) should be mentioned here, as well. Sulfur is considered to be the most promising among them. Technical sulfur is inexpensive and smallscale product. While producing sulphur asphalt the part of expensive bitumen is substituted for relatively cheap sulfur $(50 \mathrm{wt} \%)$. The result is reduction of the finished product price and 
improvement of asphalt properties. Sulfur asphalt has several unique properties such as high compressive and flexural strength, adhesion, chemical resistance, frost resistance, low water absorption and waterproofness. A major disadvantage of sulfur compositions is their low thermal stability. In addition, there is a significant change in volume during sulfur solidification due to phase transition of sulfur from a liquid to a solid state.

Mineral materials are often added to bitumen but they should be rather fillers than modifiers. For example, the wastes obtained during haydite and soda production are added to bitumen. The use of haydite dust improves crack resistance and strength characteristics of the bituminous binder. When using wastes of soda production the asphalt strength is quite high but water resistance after long-term water saturation is below limit. This problem may be solved by using silica powder. However, mineral fillers do not usually improve adhesion and/or plasticity of bitumen.

To obtain PMB, commercial bitumen of BND 60/90 for road constructions, which was produced by Lviv asphalt-bitumen storehouse, was used. Bitumen characteristics are represented in Table 2.

CIR was used as a modifier. CIR is obtained from a chemical product of coal charge coking, the characteristic of which depends on composition and quality of coal [53,54]. The synthesis procedure of coumarone-indene resins are given in [47, 51, 52]. Depending on synthesis conditions and the composition of initial raw material different CIRs were obtained. Some main properties of CIR are given in Table 2 .

A range of compounds with a relatively high content of aromatic-naphthenic based oil were used as plasticizers for the modified bitumen (Table 2), in particular: refineries;

- tars produced from West-Ukrainian and Orkhovitska oils taken at West-Ukrainian

- distillation extract of selective treatment by furfurol and residual extract of selective treatment manufactured by Ukrtatnafta, JSC;

- resin after lignitethermodestruction;

- SAE-140 transmission oil.

Resin derived from thermodestruction of lignite is one of the products obtained in the process of oxidative desulphurization [55-57].

The laboratory unit intended to obtain PMB is shown in Fig. 2. PMB has been prepared in the following way. A necessary amount of bitumen was heated to $110{ }^{\circ} \mathrm{C}$. Then the modifier and plasticizer were added in a required amount and stirred for $1 \mathrm{~h}$ at $\operatorname{Re}=1200$.

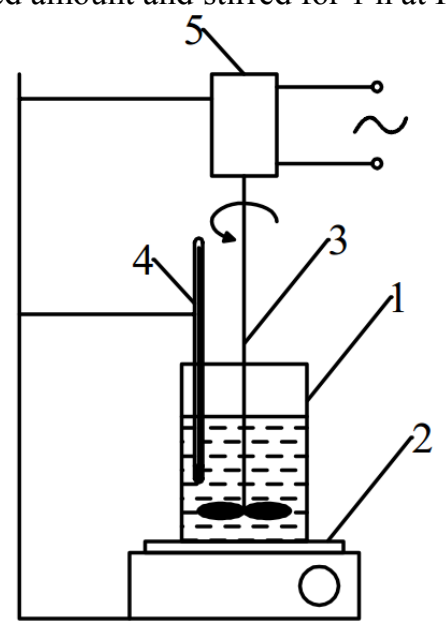

Fig. 2. The laboratory unit for obtaining PMB.

1-vessel; 2- electric heater; 3-stirrer; 4-thermometer; 5- electric motor 
Table 2

Characteristics of initial compounds

\begin{tabular}{|c|c|c|c|c|c|c|c|}
\hline \multirow[t]{2}{*}{ Index } & \multirow{2}{*}{$\begin{array}{l}\text { BND } \\
60 / 90\end{array}$} & \multirow{2}{*}{$\begin{array}{c}\text { Modifier } \\
\text { (CIR) }\end{array}$} & \multicolumn{5}{|c|}{ Plastisizers } \\
\hline & & & $\begin{array}{l}\text { Tarproduce } \\
\text { dfromWest- } \\
\text { Ukrainian } \\
\text { oils }\end{array}$ & $\begin{array}{c}\text { Tar } \\
\text { produced } \\
\text { from } \\
\text { Orkhovitska } \\
\text { oil }\end{array}$ & $\begin{array}{c}\text { Residual } \\
\text { extract of } \\
\text { oil selective } \\
\text { treatment }\end{array}$ & $\begin{array}{c}\text { Distillation } \\
\text { extract of } \\
\text { oil selective } \\
\text { treatment }\end{array}$ & $\begin{array}{c}\text { Resin of } \\
\text { lignite } \\
\text { thermodestr } \\
\text { uction }\end{array}$ \\
\hline $\begin{array}{l}\text { Penetration at } 25^{\circ} \mathrm{C} \\
\left(\mathrm{m} \times 10^{-4}\right)\end{array}$ & 62 & - & 98 & 112 & - & - & - \\
\hline $\begin{array}{l}\text { Softening point (ball \& } \\
\text { ring method) }\left({ }^{\circ} \mathrm{C}\right)\end{array}$ & 47 & $97-186$ & 43 & 38 & - & - & - \\
\hline $\operatorname{Ductility}\left(\mathrm{m} \times 10^{-2}\right)$ & & & & & & & \\
\hline at $25^{\circ} \mathrm{C}$ & 75 & - & 15 & $>100$ & - & - & - \\
\hline at $0{ }^{\circ} \mathrm{C}$ & 6 & - & - & - & - & - & - \\
\hline $\begin{array}{l}\text { Change of properties } \\
\text { after heating: }\end{array}$ & & & & & & & \\
\hline $\begin{array}{l}\text { Brittleness } \\
\text { temperature }\left({ }^{\circ} \mathrm{C}\right)\end{array}$ & -15 & - & - & - & - & - & - \\
\hline $\begin{array}{l}\text { Flash point determined } \\
\text { in open firepot }\left({ }^{\circ} \mathrm{C}\right)\end{array}$ & 235 & - & - & - & - & - & - \\
\hline $\begin{array}{l}\text { Change of weight after } \\
\text { heating }(\%)\end{array}$ & 0.2 & - & - & - & - & - & - \\
\hline Residualpenetration (\%) & 50 & - & - & - & - & - & - \\
\hline $\begin{array}{l}\text { Change of softening } \\
\text { point }\left({ }^{\circ} \mathrm{C}\right)\end{array}$ & 4 & - & - & - & - & - & - \\
\hline Adhesion to glass (\%) & 46 & - & - & - & - & - & - \\
\hline $\begin{array}{l}\text { Low-temperature } \\
\text { adhesion }(\%)\end{array}$ & 38 & - & - & - & - & - & - \\
\hline $\begin{array}{l}\text { Mass partof paraffins } \\
\text { (wt. \%) }\end{array}$ & 5.1 & - & - & - & - & - & - \\
\hline $\begin{array}{l}\text { Solubility in organic } \\
\text { solvents (\%) }\end{array}$ & 99.9 & - & - & - & - & - & - \\
\hline Penetration index & -1.0 & - & - & - & - & - & - \\
\hline Density $\left(\mathrm{kg} / \mathrm{m}^{3}\right)$ & - & - & - & - & 987.3 & 985.7 & 1048.0 \\
\hline Viscosity $\left(\mathrm{mm}^{2} / \mathrm{s}\right)$ & & & & & & & \\
\hline at $50^{\circ} \mathrm{C}$ & - & - & - & - & 128.4 & 115.4 & - \\
\hline at $80^{\circ} \mathrm{C}$ & - & - & - & - & - & - & 33.08 \\
\hline at $100^{\circ} \mathrm{C}$ & - & - & - & - & 11.8 & 10.3 & - \\
\hline Freezing point, ${ }^{\circ} \mathrm{C}$ & - & - & - & - & - & - & 42 \\
\hline Molecular weight & - & $820 * *$ & - & - & - & - & - \\
\hline $\begin{array}{l}\text { Bromine number, g } \\
\mathrm{Br}_{2} / 100 \text { g CIR }\end{array}$ & - & $27.5 * *$ & - & - & - & - & - \\
\hline
\end{tabular}

\section{*DSTU - Ukrainian National standards}

$* *$ Determined for CIR with the softening temperature of $135^{\circ} \mathrm{C}$.

Chemical group composition of the bitumen was analyzed by the Marcusson method. The type of the structure of the bitumen sampled was determined according to this procedure (Table 3). 
Group analysis and type of the initial bitumen structure

\begin{tabular}{|c|c|c|c|c|c|c|}
\hline \multirow{2}{*}{ Type of structure } & \multicolumn{4}{|c|}{ Group composition, wt \% } & \multicolumn{2}{c|}{ Ratio } \\
\cline { 2 - 7 } & $\begin{array}{c}\text { Carbenes, carboids and } \\
\text { mechanical impurities }\end{array}$ & $\begin{array}{c}\text { Asphaltenes } \\
(\mathrm{A})\end{array}$ & $\begin{array}{c}\text { Resins } \\
(\mathrm{R})\end{array}$ & Oils (O) & $\mathrm{A} /(\mathrm{A}+\mathrm{R})$ & $\mathrm{A} /(\mathrm{O}+\mathrm{R})$ \\
\hline I type - gel & - & $>25$ & $<24$ & $>50$ & $>0.50$ & $>0.35$ \\
II type - zol & - & $<18$ & $>35$ & $\leq 47$ & $<0.34$ & $<0.22$ \\
III type - zol-gel & - & $21-23$ & $30-34$ & $45-49$ & $0.39-0.49$ & $0.25-0.30$ \\
\hline
\end{tabular}

Technical parameters of the raw material and products were determined according to standard procedures (see tables 1,2). The value of low-temperature adhesion which characterizes the dependence of bitumen adhesion on great temperature difference was determined according to the devised procedure. Differential-thermal analysis (DTA) of the initial and modified bitumen was done on a Q-1500D derivatograph (system F. Paulik, J. Paulik and L. Erdey) in a dynamic mode at the heating rate of $10{ }^{\circ} \mathrm{C} / \mathrm{min}$ under atmosphere of air. The weight of the sample was equal to 200 mg. An analytical signal of mass loss and thermal effects were registrated via the computer. Aluminium oxide was used as a standard.

To determine the adequacy of mathematical model the mean relative error of approximation was calculated according to the formula.

$$
\varepsilon_{j}=\frac{1}{n} \sum_{j=1}^{n}\left|\frac{y_{i j}-Y_{i j}^{r e g}}{Y_{i j}}\right|
$$

where $Y_{i j}$ - experimental values; $Y_{i j}^{\text {reg }}$ - values of response function calculated according to regression equations; $n$ - number of experiments.

To evaluate the effect of resin indices (softening temperature, in particular) on the properties of road bitumen we prepared a series of PMB samples with the softening temperature of $52{ }^{\circ} \mathrm{C}$. The results are represented in Table 4.

Table 4

Dependence of PMBs properties on CIR softening temperature

\begin{tabular}{|c|c|c|c|c|c|c|c|}
\hline Index & \multicolumn{7}{|c|}{ Value } \\
\hline \multicolumn{8}{|c|}{ Conditions of PMB obtaining } \\
\hline Bitumen content (wt. \%) & 100.0 & 88.0 & 91.9 & 92.7 & 93.3 & 93.6 & 95.0 \\
\hline CIR content (wt. \%) & 0.0 & 12.0 & 8.1 & 7.3 & 6.7 & 6.4 & 5.0 \\
\hline Softening point of CIR (ball \& ring method) $\left({ }^{\circ} \mathrm{C}\right)$ & - & 97 & 120 & 128 & 135 & 140 & 186 \\
\hline Molecular weight of CIR & - & 680 & 760 & 765 & 810 & 830 & - \\
\hline \multicolumn{8}{|c|}{ Characteristics of PMB } \\
\hline Softening point of PMB (ball \& ring method) $\left({ }^{\circ} \mathrm{C}\right)$ & 47 & 52 & 52 & 52 & 52 & 52 & 52 \\
\hline Ductility at $25^{\circ} \mathrm{C}\left(\mathrm{m} \times 10^{-2}\right)$ & 75 & 45 & 46 & 38 & 36 & 33 & 21 \\
\hline Penetration at $25^{\circ} \mathrm{C}\left(\mathrm{m} \times 10^{-4}\right)$ & 62 & 53 & 51 & 37 & 38 & 37 & 25 \\
\hline Adhesion to glass (\%) & 46 & 77 & 85 & 100 & 100 & 100 & 100 \\
\hline Low-temperature & 38 & 70 & 74 & 97 & 98 & 100 & 100 \\
\hline
\end{tabular}

The obtained results allow to assert that the increase in polymerization degree (softening temperature) of the resins increases PMB adhesion including that at low temperatures. To prepare PMB with good adhesive properties it is necessary to use CIR with the softening temperature no lessthan $128-140^{\circ} \mathrm{C}$. On the other hand, it is complicated (from the technological point of view) to obtain CIR with such softening temperature. Moreover, with the increase in softening temperature 
PMB plastic properties are deteriorated (penetration and ductility are decreased). Therefore, for the further investigations we used CIR with the softening temperature of $135{ }^{\circ} \mathrm{C}$.

The results of the studies are given in Table 5 in terms of how plasticizers affect the properties of PMBs obtained.The quantity of plasticizer (see Table 5), obtained from oil stock (samples 3-7) was equalto $8 \mathrm{wt} \%$. To compare the plasticizer obtained from brown coal (sample 2) and the best plasticizer from oil stock (sample 3) we fitted the composition of the sample 2 in such a way, that its softening point was the same as that for the sample $3\left(52^{\circ} \mathrm{C}\right)$.

The Table 5 shows that PMB with no plasticizer added (Sample 1) was obtained using CIR and does not conform to the requirements [47] (Table 1) by penetration index. Adding the plasticizer to PMB in most cases (Table 5):

- decreases softening points;

- makes adhesion worse;

- increases penetration.

Table 5 demonstrates that resin of thermodestruction of lignite and tar from West-Ukrainian oil most effectively increase penetration and least of all enhance a decrease in softening points and ductility. The properties of Samples 2 and 3 actually meet the requirements suggested [47].

Considering that resin derived from the lignite thermodestruction is a product being currently produced only in laboratory, it was decided to use the tar from West-Ukrainian oil (TWUO) as a plastisizer in further researches.

To establish the optimal composition of bitumen-CIR-TWUO mixture, the empiric mathematical models were developed on the basis of full-factorial experiments (Table 6). The models describe the dependence of PMB properties on its composition. The mathematical dependence of response function (Y) on individual components content (X) was developed as a linear function:

$$
Y_{i}=B_{0}+B_{1} \cdot X_{1}+B_{2} \cdot X_{2}
$$

For response function and main parameters of obtaining $\mathrm{PMB}$, the following symbols were used: $\mathrm{Y}_{1}-\mathrm{PMB}$ softening point, ${ }^{\circ} \mathrm{C} ; \mathrm{Y}_{2}$-depth of needle penetration at $25{ }^{\circ} \mathrm{C}, 0.1 \mathrm{~mm} ; \mathrm{X}_{1}-\mathrm{CIR}$ amount, wt \%; $\mathrm{X}_{2}$-plasticizer amount, wt \%.

Table 5

Effect of plasticizer nature on PMB properties

\begin{tabular}{|c|c|c|c|c|c|c|c|c|}
\hline \multirow{2}{*}{$\begin{array}{c}\text { Sam } \\
\text { ple } \\
\text { num } \\
\text { ber }\end{array}$} & \multirow[b]{2}{*}{ Plasticizer } & \multicolumn{3}{|c|}{$\begin{array}{l}\text { Blend composition,wt. } \\
\%\end{array}$} & \multicolumn{4}{|c|}{ Main characteristics of obtained PMB } \\
\hline & & $\begin{array}{l}\text { bitu } \\
\text { men }\end{array}$ & ICR & plasticizer & $\begin{array}{l}\text { Softening point } \\
\text { (ball \& ring } \\
\text { method) }\left({ }^{\circ} \mathrm{C}\right)\end{array}$ & $\begin{array}{c}\text { Ductility at } \\
25^{\circ} \mathrm{C}\left(\mathrm{m} \cdot 10^{-2}\right)\end{array}$ & $\begin{array}{c}\text { Penetration at } \\
25^{\circ} \mathrm{C}\left(\mathrm{m} \times 10^{-4}\right)\end{array}$ & $\begin{array}{c}\text { Adhesion } \\
\text { to glass } \\
(\%)\end{array}$ \\
\hline 1 & 2 & 3 & 4 & 5 & 6 & 7 & 8 & 9 \\
\hline 1 & - & 93.0 & 7.0 & 0 & 52 & 36 & 38 & 100 \\
\hline 2 & $\begin{array}{l}\text { Resin of lignite } \\
\text { thermodestruc- } \\
\text { tion }\end{array}$ & 84.0 & 7.0 & 9.0 & 52 & 28 & 62 & 100 \\
\hline 3 & $\begin{array}{l}\text { Tarproduced } \\
\text { from West- } \\
\text { Ukrainianoils }\end{array}$ & 85.0 & 7.0 & 8.0 & 52 & 26 & 60 & 93 \\
\hline
\end{tabular}


Table 5 continue

\begin{tabular}{|c|c|c|c|c|c|c|c|c|}
\hline \multirow{2}{*}{$\begin{array}{c}\text { Sam } \\
\text { ple } \\
\text { num } \\
\text { ber }\end{array}$} & Plasticizer & \multicolumn{2}{|c|}{$\begin{array}{c}\text { Blend } \\
\text { composition, wt. \% }\end{array}$} & \multicolumn{4}{c|}{ Main characteristics of obtained PMB } \\
\cline { 3 - 9 } & $\begin{array}{c}\text { bitu } \\
\text { men }\end{array}$ & ICR & plasticizer & $\begin{array}{c}\text { Softening point } \\
\text { (ball \& ring } \\
\text { method) }\left({ }^{\circ} \mathrm{C}\right)\end{array}$ & $\begin{array}{c}\text { Ductility at } \\
25^{\circ} \mathrm{C}\left(\mathrm{m} \cdot 10^{-2}\right)\end{array}$ & $\begin{array}{c}\text { Penetration at } \\
25{ }^{\circ} \mathrm{C}\left(\mathrm{m}^{\prime} \times 10^{-4}\right)\end{array}$ & $\begin{array}{c}\text { Adhesion } \\
\text { to glass } \\
(\%)\end{array}$ \\
\hline 5 & $\begin{array}{c}\text { Residual extract } \\
\text { of selective } \\
\text { treatment }\end{array}$ & 85.0 & 7.0 & 8.0 & 49 & 55 & 55 & 84 \\
\hline 6 & $\begin{array}{c}\text { Tar produced } \\
\text { from } \\
\text { Orkhovitska oil } \\
\text { (Ukraine) }\end{array}$ & 85.0 & 7.0 & 8.0 & 52 & 21 & 40 & 78 \\
\hline 7 & $\begin{array}{c}\text { SAE 140 } \\
\text { transmission oil }\end{array}$ & 85.0 & 7.0 & 8.0 & 46 & 41 & 65 & 51 \\
\hline $\begin{array}{c}\text { Distillation } \\
\text { extract of } \\
\text { selective } \\
\text { treatment }\end{array}$ & 85.0 & 7.0 & 8.0 & 47 & 51 & 61 & 48 \\
\hline
\end{tabular}

The following regression equations were obtained:

$$
\begin{aligned}
& Y_{1}=48.49+0.75 \cdot X_{1}+0.13 \cdot X_{2} \\
& Y_{2}=70.12+3.02 \cdot X_{1}+1.38 \cdot X_{2}
\end{aligned}
$$

Substituting the values of $X_{1}$ and $X_{2}$ into Eqs. (3) and (4), the values of response function $\left(Y_{i j}^{r e g}\right)$ and relative errors of experimental statistical model for every experiment were found. These values are represented in Table 6.

Table 6

\begin{tabular}{|c|c|c|c|c|c|c|c|c|}
\hline \multirow{2}{*}{ № } & \multirow{2}{*}{$\mathrm{X}_{1}($ wt. \%) } & \multirow{2}{*}{$\mathrm{X}_{2}$ (wt. \%) } & \multirow{2}{*}{$\begin{array}{c}\mathrm{Y}_{1} \\
\left({ }^{\circ} \mathrm{C}\right)\end{array}$} & \multirow{2}{*}{$Y_{1}^{r e g}\left({ }^{\circ} \mathrm{C}\right)$} & \multirow{2}{*}{$\mathrm{Y}_{2}\left(\mathrm{~m} \cdot 10^{-4}\right)$} & \multirow{2}{*}{$Y_{2}^{r e g}\left(\mathrm{~m} \cdot 10^{-4}\right)$} & \multicolumn{2}{|c|}{ Relative errors } \\
\hline & & & & & & & $\varepsilon_{1}$ & $\varepsilon_{2}$ \\
\hline 1 & 7 & 3 & 50 & 52.95 & 43 & 53.26 & 0.0590 & 0.2386 \\
\hline 2 & 13 & 3 & 54 & 57.45 & 35 & 35.26 & 0.0639 & 0.0074 \\
\hline 3 & 7 & 11 & 49 & 51.91 & 65 & 64.30 & 0.0594 & 0.0108 \\
\hline 4 & 13 & 11 & 53 & 56.41 & 35 & 46.30 & 0.0643 & 0.3229 \\
\hline & & Mean rela & error & proximati & $(\varepsilon)$ & & 0.0617 & 0.1449 \\
\hline
\end{tabular}

Experimental data, calculated values of response functions, and relative errors

Mean relative errors of approximation are: $\varepsilon_{1}=0.0617(6.17 \%), \varepsilon_{2}=0.1449(14.49 \%)$. It is assumed that at $\varepsilon=0-10 \%$ the accuracy of prediction is high, at $\varepsilon=10-20 \%-\operatorname{good}$ and at $\varepsilon=20$ $50 \%$ - fair. Thus, the models developed correlate well with experimental data.

Graphical interpretation of Eqs. (3) and (4) is given in Figs. 3 and 4. 


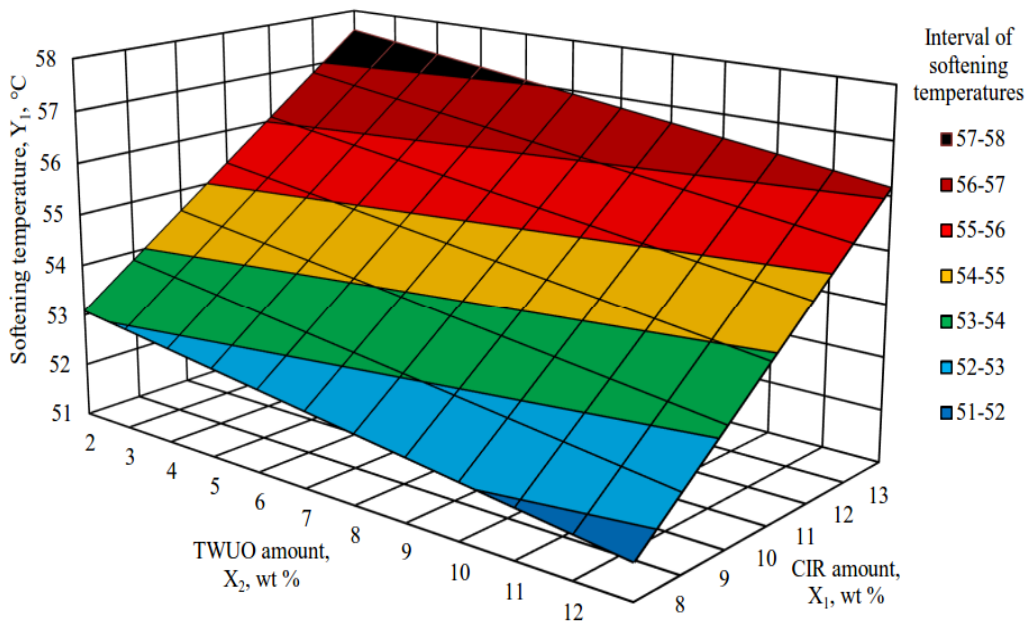

Fig. 3. Effect of CIR and TWUO amount on PMB softening point

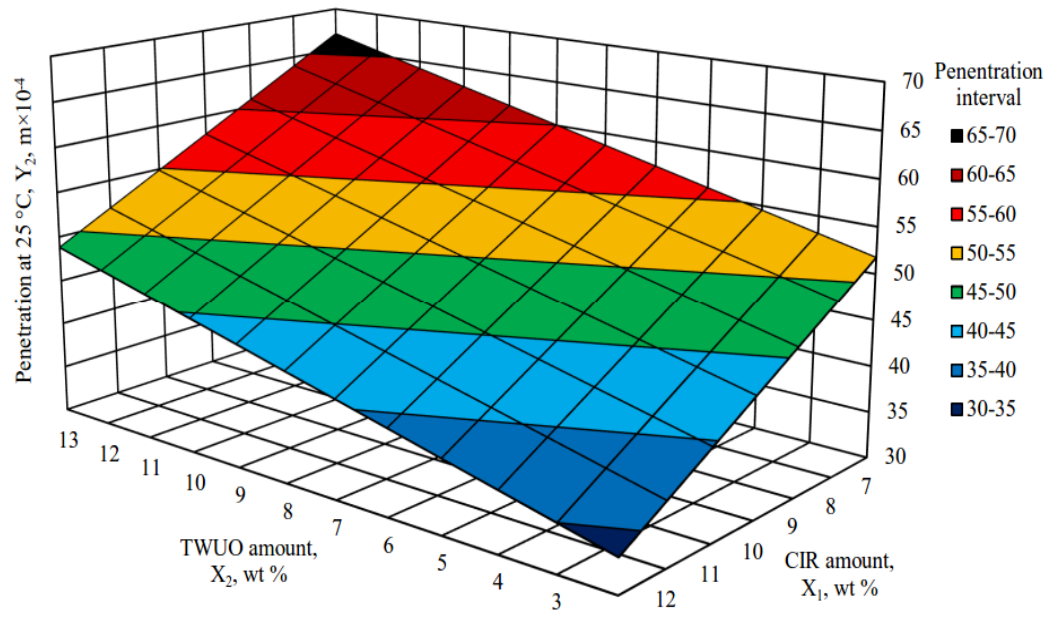

Fig. 4. Effect of CIR and TWUO amount on PMB penetration

Fig. 3 shows that an increase in the CIR amount and a decrease in the plasticizer amount (tar produced from West-Ukrainian oils) give rise to the softening point. The increasing penetration (Fig. 4) is accompanied by an opposite tendency: the CIR amount decreases while the amount of plasticizer increases. Therefore, the amount CIR and plasticizer in the blend should be optimum.

On the basis of regression equations using the method of uniform search of response functions, optimal amounts of components were found, which would provide the necessary values of main parameters (response functions) of the process effectiveness, namely: softening point above $52{ }^{\circ} \mathrm{C}$ and the depth of needle penetration at $25{ }^{\circ} \mathrm{C}$ - above $61{ }^{\circ} \mathrm{C}$. PMB I was obtained at optimal amount of CIR $7 \mathrm{wt} \%$ and tar amount of $8 \mathrm{wt} \%$. PMB II was obtained for the comparison. It consists of bitumen (91.5 wt \%), Kraton D 1192 commercial modifier (1.5 wt \%) and tar produced from West-Ukrainian oil as the plasticizer (7 wt \%). PMB II composition was fitted in such a way that its softening temperature was equal to the softening point of PMB I. PMB characteristics are presented in Table 7. 
Table 7

PMB characteristics

\begin{tabular}{|c|c|c|c|}
\hline \multirow{2}{*}{ Index } & \multirow{2}{*}{$\begin{array}{c}\text { Standard for BMP } \\
\text { 60/90-52 according to } \\
\text { DSTUBV.2.7-135:2007* }\end{array}$} & \multicolumn{2}{|c|}{ Actual values } \\
\hline & & PMB I & PMB II \\
\hline Homogeneity & Homogeneous & Homogeneous & Homogeneous \\
\hline Penetration at $25^{\circ} \mathrm{C}\left(\mathrm{m} \cdot 10^{-4}\right)$ & $61-90$ & 62 & 61 \\
\hline Softening point (ball \& ring method) $\left({ }^{\circ} \mathrm{C}\right)$ & $\geq 52$ & 52 & 52 \\
\hline \multicolumn{4}{|l|}{ Ductility $\left(\mathrm{m} \cdot 10^{-2}\right)$} \\
\hline at $25^{\circ} \mathrm{C}$ & $\geq 25$ & 26 & 36 \\
\hline at $0{ }^{\circ} \mathrm{C}$ & $\geq 5,0$ & 6 & 5 \\
\hline Elasticity at $25^{\circ} \mathrm{C}(\%)$ & $\geq 50$ & 52 & 54 \\
\hline Brittleness temperature $\left({ }^{\circ} \mathrm{C}\right)$ & $\leq-15$ & -16 & -15 \\
\hline Flash point determined in open firepot $\left({ }^{\circ} \mathrm{C}\right)$ & $\geq 230$ & 236 & 236 \\
\hline \multicolumn{4}{|l|}{ Change of properties after heating: } \\
\hline Change of softening point $\left({ }^{\circ} \mathrm{C}\right)$ & $\leq 6$ & 5 & 5 \\
\hline Residual penetration $(\%)$ & $\geq 60$ & 61 & 62 \\
\hline Adhesion to glass (\%) & $\geq 75$ & 93 & 90 \\
\hline Low-temperature adhesion (\%) & - & 82 & 74 \\
\hline \multicolumn{4}{|l|}{ Destruction while storage: } \\
\hline Difference between softening points $\left({ }^{\circ} \mathrm{C}\right)$ & $\leq 8$ & 8 & 8 \\
\hline $\begin{array}{l}\text { Difference between penetrations at } 25{ }^{\circ} \mathrm{C} \\
\left(\mathrm{m} \cdot 10^{-4}\right)\end{array}$ & $\leq 30$ & 22 & 25 \\
\hline
\end{tabular}

*DSTU is Ukrainian National standards

Both samples with CIR used and PMB based on a commercial additive meet the requirements DSTU B V.2.7-135:2007, and PMB Imay be used to produceSlurry Seal [47]. Both types of bitumen have satisfactory aging properties (change of properties after heating, destruction while storage). Theplasticityproperties (ductilityandelasticityat $25^{\circ} \mathrm{C}$ ) aresomewhatbetterforPMBII butPMBIhasbetteroperationalcharacteristicsat low temperatures (ductilityat $0{ }^{\circ} \mathrm{C}$, brittlenesstemperature). It should be noted that adhesion, including low-temperature adhesion, is higher for PMB I. It means that CIR is an effective modifier of petroleum bitumen.

Group compositions of the binders are given in Table 8 . When comparing the structure of the initial bitumen with the modified one, it may be asserted that bitumens upon their modification are converted from gel-structure into zol-structure. This explains why rheological and plastic properties are improved. The zol-gel structure is considered to be optimal for binders used in road constructions.

Table 8

Group analysis of the modified bitumen

\begin{tabular}{|c|c|c|c|}
\hline Component & $\begin{array}{c}\text { Oxidated bitumen } \\
\text { (non-modified) }\end{array}$ & PMB I & PMB II \\
\hline 1 & 2 & 3 & 4 \\
\hline $\begin{array}{l}\text { Carbenes, carboids and mechanical } \\
\text { impurities }\end{array}$ & 0.6 & 0.4 & 0.5 \\
\hline
\end{tabular}


Table 8 continue

\begin{tabular}{|l|c|c|c|}
\hline Component & $\begin{array}{c}\text { Oxidated bitumen } \\
\text { (non-modified) }\end{array}$ & PMB I & PMB II \\
\hline \multicolumn{1}{|c|}{1} & 2 & 3 & 4 \\
\hline Asphaltene & 25.3 & 22.0 & 23.4 \\
Resins & 24.2 & 35.8 & 33.1 \\
Oils & 49.9 & 41.8 & 43.0 \\
Structure & Gel & Zol-gel & Zol-gel \\
A/(O+R) & 0.34 & 0.30 & 0.28 \\
A/(A+R) & 0.51 & 0.41 & 0.37 \\
\hline
\end{tabular}

The results of TG and DTA for the initial bitumen, PMB I and PMB II are represented in figs. 5 and 6 , respectively.

The smallest mass loss is observed for PMB II (Fig. 5), that is why this type of binder may be used at high temperatures.Using PMB I at high temperatures (above $100-150{ }^{\circ} \mathrm{C}$ ) is undesirable because a considerable mass loss is observed in such a case $(0.13 \%)$.

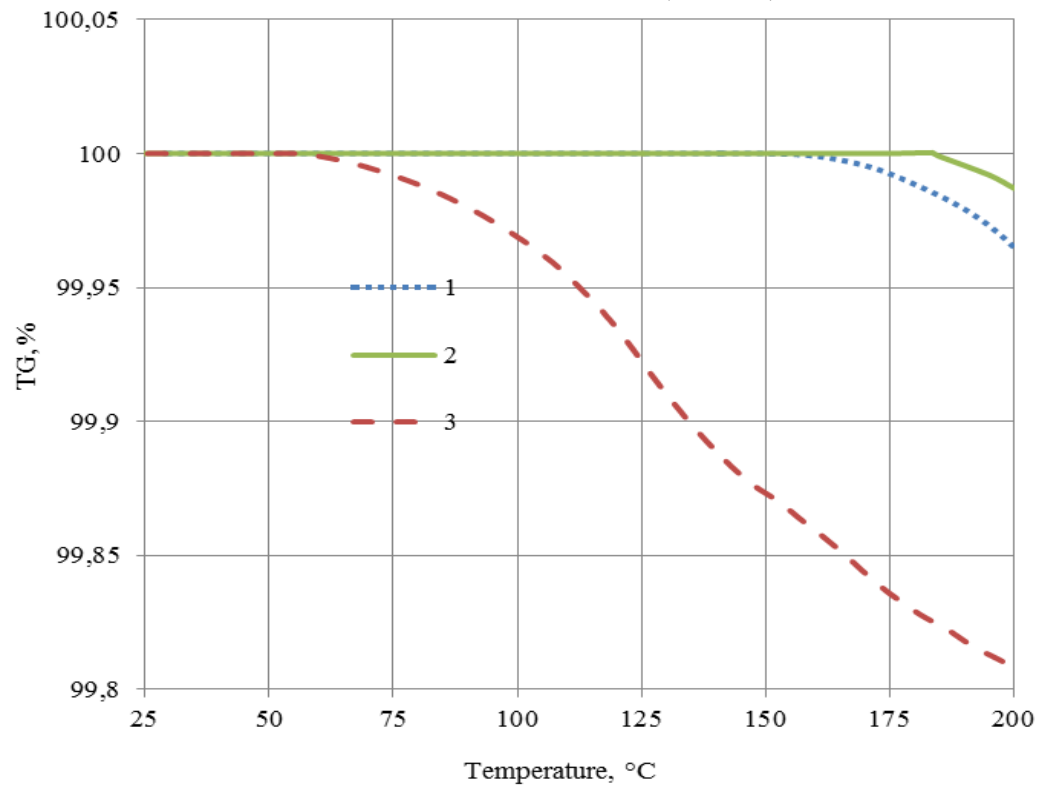

Fig. 5. Mass losses vs. temperature. 1 - initial bitumen; 2 - PMB II; 3 - PMB I

So, the modification of bitumen by CIR is recommended to be used under low temperatures, for example for emulsion technology.

DTA indicates that the deepest endothermal effect is observed for PMB I within $20-100{ }^{\circ} \mathrm{C}$ (Fig. 6) indicating its higher thermal stability as compared with PMB II and the initial bitumen. The bitumen-based asphalt modified by CIR will be less strained during the hot season.

The wide phenolic fraction (WPhF) was sampled at Zaporizhkoks PJSC for investigations. The WPhF characteristic is given in Table 1. For the purpose of concentration (separation) of phenol and cresols, the WPhF was divided into two fractions, an initial boiling point (IBP $\sim 92{ }^{\circ} \mathrm{C}$ ) -185 and 185 an end boiling point (EBP $\sim 211^{\circ} \mathrm{C}$ ) ${ }^{\circ} \mathrm{C}$ (the boiling point of phenol is $182{ }^{\circ} \mathrm{C}$, of cresols $-191-202{ }^{\circ} \mathrm{C}$ ). Table 1 lists the characteristic of fractions derived. The mass balance of distillation is shown in Table 9. 


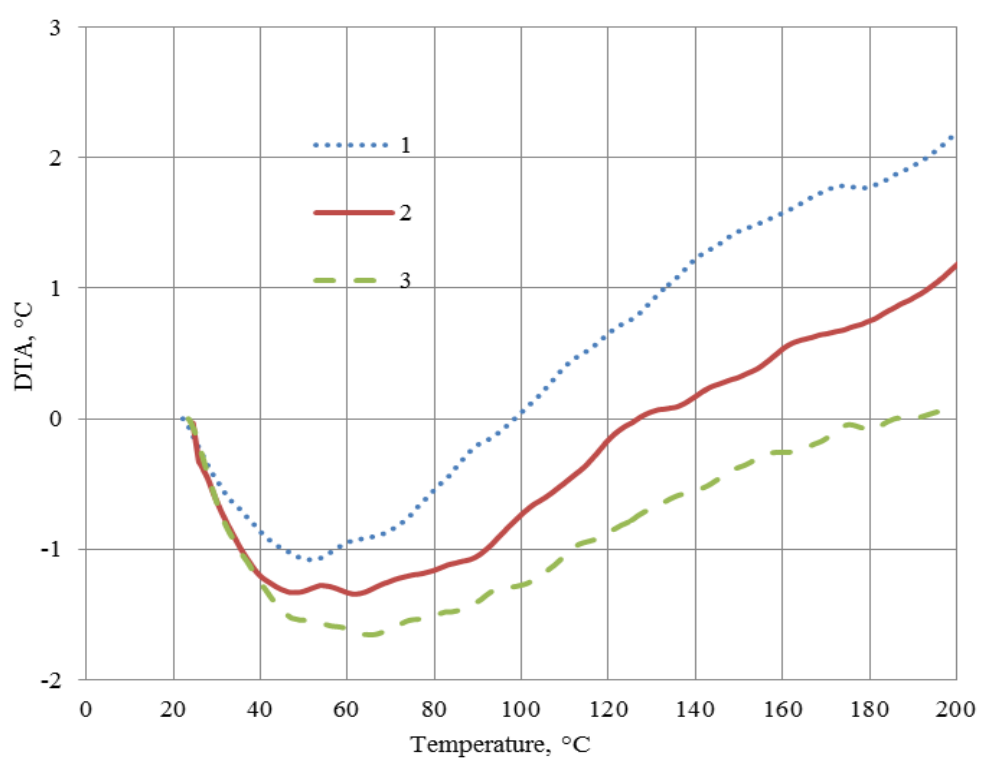

Fig. 6. DTA in the air flow ( 1 initial bitumen; 2 PMB II; 3 PMB I)

Characteristics of a starting material

\begin{tabular}{|l|c|c|c|c|}
\hline \multicolumn{1}{|c|}{ Indexes } & \multicolumn{3}{|c|}{ Values } & \multirow{2}{*}{ Procedure } \\
\cline { 2 - 4 } & $\begin{array}{c}\text { wide phenolic } \\
\text { fraction }(\mathrm{WPhF})\end{array}$ & $\begin{array}{c}\text { Fraction } \\
\text { IBP }-185{ }^{\circ} \mathrm{C}\end{array}$ & $\begin{array}{c}\text { Fraction } \\
185-\text { EBP }{ }^{\circ} \mathrm{C}\end{array}$ & \\
\hline Distillation $\left({ }^{\circ} \mathrm{C}\right):$ & 105 & 92 & 172 & \\
Initial boiling point & 164 & 147 & 177 & \\
$10 \%$ distilled at the temperature & 172 & 156 & 179 & \\
$20 \%$ distilled at the temperature & 174 & 161 & 181 & \\
$30 \%$ distilled at the temperature & 177 & 166 & 183 & \\
$40 \%$ distilled at the temperature & 179 & 169 & 184 & GOST 2177 \\
$50 \%$ distilled at the temperature & 182 & 172 & 187 & \\
$60 \%$ distilled at the temperature & 185 & 174 & 190 & \\
$70 \%$ distilled at the temperature & 197 & 181 & 200 & \\
$80 \%$ distilled at the temperature & 202 & 184 & 206 & \\
$90 \%$ distilled at the temperature & 208 & 189 & 211 & \\
$95 \%$ distilled at the temperature & 136 & 108 & 167 & \\
Molecular weight & 81.64 & 81.28 & 75.84 & GOST 8997-89 \\
Bromine number $(\mathrm{g}$ Br $2 / 100 \mathrm{~g}$ product) & & & & \\
\hline
\end{tabular}


Mass balance of the WPhF distillation.

\begin{tabular}{|l|c|}
\hline \multicolumn{1}{|c|}{ Article } & Yield by weight, $\%$ \\
\hline Fraction IBP $-185^{\circ} \mathrm{C}$ (phenol concentrate) & 50.60 \\
Fraction $185-\mathrm{EBP}{ }^{\circ} \mathrm{C}$ (cresols concentrate) & 46.77 \\
Distillation residue & 2.63 \\
\hline Total & 100.00 \\
\hline
\end{tabular}

Phenol and its derivatives hereinafter called raw (technical) phenols - RPh1, RPh2 and $\mathrm{RPh} 3$ - were separated from the $\mathrm{WPhF}$, the fraction IBP -185 and the fraction $185-\mathrm{EBP}{ }^{\circ} \mathrm{C}$ by using a $20 \% \mathrm{NaOH}$ solution. The removal of phenols with the solution of $\mathrm{NaOH}$ was based on the fact that phenol and its derivatives form water-soluble phenolates. The latter were made into phenols by using the concentrated hydrochloric acid. The yield of raw phenols with the WPhF, the fraction IBP - 185 and the fraction $185-\mathrm{EBP}{ }^{\circ} \mathrm{C}$ accounted for $32.3,32.0$ and $35.1 \% \mathrm{wt}$, respectively.

The resins were derived from initial fractions and those raw phenols that were obtained from them by the method of formaldehyde condensation polymerization.

The scheme of the research is given in Fig. 7.

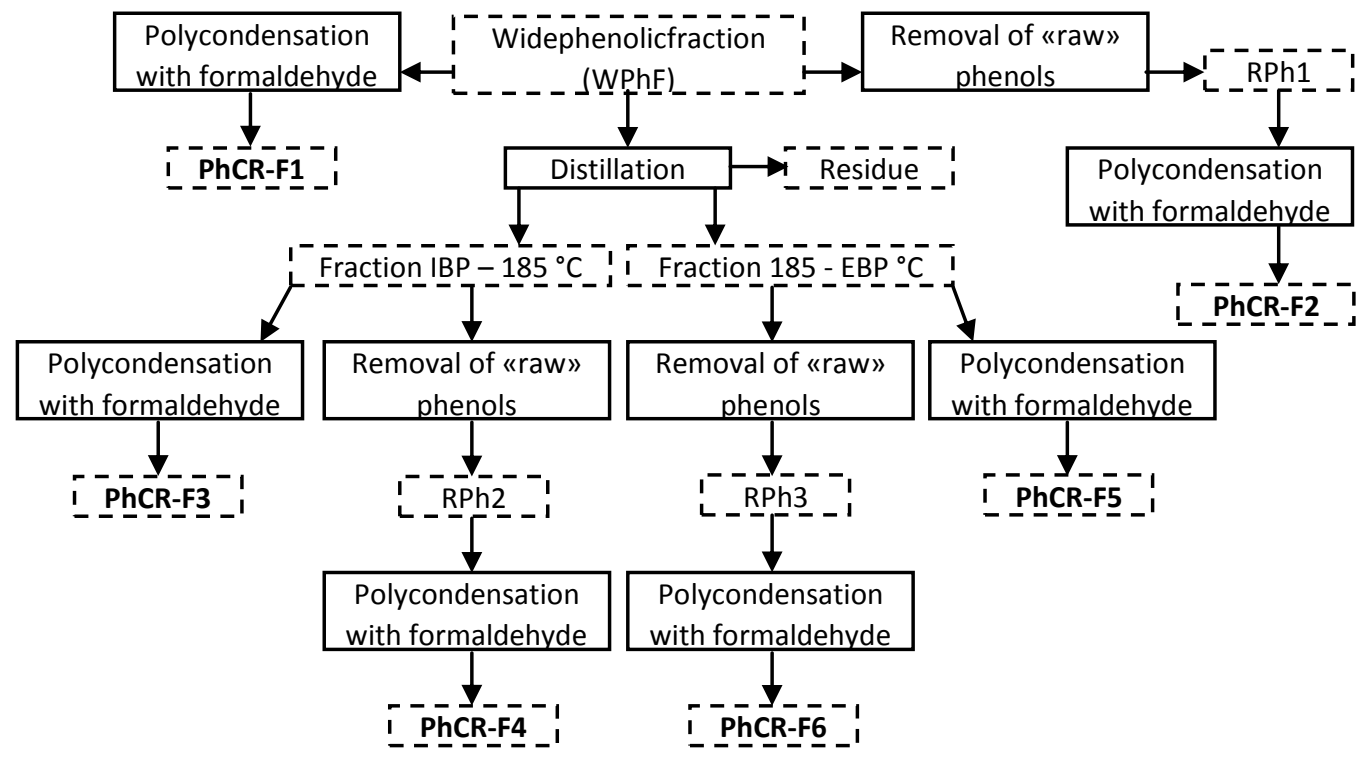

Fig. 7. Scheme ofthe research: PhCR-F - phenol-cresol-formaldehyde resin; RPh - raw (technical) phenols

The process of formaldehyde condensation polymerization of phenols was carried out on the laboratory setup depicted in Fig. 2. The raw material was placed in a three-pipe reactor and heated while stirring at $100{ }^{\circ} \mathrm{C}$ in a thermostat. Then, a necessary amount of formalin (a weight content of formaldehyde in formalin equaled $37 \%$ ) was added along with a concentrated hydrochloric acid (catalyst), followed by recording the start of the process that was done for $60 \mathrm{~s}$. As the synthesis is over, a hot reaction mixture, obtained from raw phenols, was poured into a glass. After cooling the mixture, an aqueous phase was drained and the resin was exposed to the 3-hour drying in a vacuum dryer at $100{ }^{\circ} \mathrm{C}$. When the $\mathrm{WPhF}$ was used as the starting material, the fraction IBP -185 and the fraction $185-\mathrm{EBP}{ }^{\circ} \mathrm{C}$, at first there was the distillation of water and unreacted constituents carried 
out under vacuum. After that the resulting resin was dried some more in the vacuum dryer for 3 hours at $100{ }^{\circ} \mathrm{C}$. The yield of the resins obtained was determined by the weighing of the starting material and the phenol-cresol-formaldehyde resins (PhCR-F).

In order to obtain PMBs, the distillate (residual) petroleum-derived bitumen for roads of the BD 60/90 grade and the BND 60/90 oxidized petroleum-derived bitumen for roads were utilized.

The BD 60/90 distillate (residual) petroleum road bitumen was selected at the road maintenance department of Frankivsk region (Lviv city). The oxidized petroleum-derived road bitumen of the BND 60/90 grade was sampled at Ukrtatnafta PJSC (the city of Kremechuk).

The PMB has been prepared by virtue of mixing in the following sequence: a necessary amount of bitumen was heated while stirring $(\mathrm{Re}=1200)$ to the temperature of modification. Then with a required amount of the modifier added, it was sustained for 1 hour.

Novolac phenol-cresol-formaldehyde resins were obtained according to the scheme given in Figure 1 by the method of formaldehyde condensation polymerization with the WPhF, the fraction IBP -185 and the fraction $185-\mathrm{EBP}{ }^{\circ} \mathrm{C}$ and from the raw phenols extracted from these fractions. Synthesis conditions for the resins were set out on the basis of [58] and are shown in Table 11. As recommended by [58], the obtaining of novolac phenol-formaldehyde resins requires maintaining the mole ratio of phenol to formaldehyde at 1.12-1.42, while for novolac cresolformaldehyde resins it should equal 2.27. Considering that the raw phenols that were derived from the phenolic fraction of coal tar contain both phenols and cresols at various ratios, the syntheses were done at the mole ratio of raw phenols to formaldehydes at the value of 1.42 . For calculations of reactor loading, it was assumed that the molar mass of the resulting raw phenols was $94.1 \mathrm{~g} / \mathrm{mole}$, which is equal to the molecular weight of pure phenol. The effect of the ratio of reaction constituents on the production of resin will be looked into in further studies.

Table 11

Synthesis conditions for PhCR-F

\begin{tabular}{|l|c|}
\hline \multicolumn{1}{|c|}{ Parameter } & Value \\
\hline *Mole ratio of raw phenols to formaldehyde & 1.42 \\
Weight ratio of raw phenols to formalin (formaldehyde content in formalin $-37 \% \mathrm{wt})$ & 1.78 \\
Catalyst weight content (concentrated $\mathrm{HCl}$ ), \% by raw phenols & 1.0 \\
Temperature, ${ }^{\circ} \mathrm{C}$ & 100 \\
Process duration, min & 60 \\
\hline
\end{tabular}

*The molar mass of raw phenols was proposed to be $94.1 \mathrm{~g} / \mathrm{mol}$.

The mass balance for the obtaining of phenol-cresol-formaldehyde resins is given in Table12.

Table 12

Mass balances involved in syntheses for the obtaining of PhCR-F.

\begin{tabular}{|l|c|c|c|c|c|c|}
\hline \multicolumn{1}{|c|}{ Article } & PhCR-F1 & PhCR-F2 & PhCR-F3 & PhCR-F4 & PhCR-F5 & PhCR-F6 \\
\hline \multicolumn{1}{|c|}{1} & 2 & 3 & 4 & 5 & 6 & 7 \\
\hline 1. Starting material & $\mathrm{WPhF}$ & $\mathrm{RPh} 1$ & fr. IBP-185 ${ }^{\circ} \mathrm{C}$ & $\mathrm{RPh} 2$ & fr. 185-EBP ${ }^{\circ} \mathrm{C}$ & $\mathrm{RPh} 3$ \\
g & 100.00 & 32.30 & 50.60 & 16.19 & 46.80 & 16.43 \\
\% wt to be loaded & 84.42 & 63.64 & 84.54 & 63.64 & 83.30 & 63.64 \\
wt for a frond-end fraction & $10.00^{1}$ & $32.30^{1}$ & $100.00^{2}$ & $32.00^{2}$ & $100.00^{3}$ & $35.10^{3}$ \\
\% wt for WPhF & 100.00 & 32.30 & 50.60 & 16.19 & 46.80 & 16.43 \\
\hline
\end{tabular}


Table 12 continue

\begin{tabular}{|c|c|c|c|c|c|c|}
\hline 1 & 2 & 3 & 4 & 5 & 6 & 7 \\
\hline \multicolumn{7}{|c|}{ Loaded } \\
\hline 2. Formalin & $\mathrm{WPhF}$ & $\mathrm{RPh} 1$ & fr. IBP- $185^{\circ} \mathrm{C}$ & $\mathrm{RPh} 2$ & fr. 185 -EBP ${ }^{\circ} \mathrm{C}$ & $\mathrm{RPh} 3$ \\
\hline$\% \mathrm{wt}$ for a frond-end fraction & $18.13^{1}$ & $18.13^{1}$ & $17.96^{2}$ & $17.96^{2}$ & $19.70^{3}$ & $19.70^{3}$ \\
\hline$\%$ wt for $\mathrm{WPhF}$ & 18.13 & 18.13 & 9.09 & 9.09 & 9.22 & 9.22 \\
\hline \multicolumn{7}{|l|}{ 3. Concentrated $\mathrm{HCl}$} \\
\hline g & 0.32 & 0.32 & 0.16 & 0.16 & 0.16 & 0.16 \\
\hline$\%$ wt to be loaded & 0.27 & 0.64 & 0.27 & 0.64 & 0.29 & 0.64 \\
\hline$\% \mathrm{wt}$ for a frond-end fraction & $0.32^{1}$ & $0.32^{1}$ & $0.32^{2}$ & $0.32^{2}$ & $0.35^{3}$ & $0.35^{3}$ \\
\hline$\%$ wt for $\mathrm{WPhF}$ & 0.32 & 0.32 & 0.16 & 0.16 & 0.16 & 0.16 \\
\hline Total, g & 118.45 & 50.75 & 59.85 & 25.44 & 56.18 & 25.81 \\
\hline \multicolumn{7}{|c|}{ Results } \\
\hline 1. Tar & & & & & & \\
\hline $\mathrm{g}$ & 18.20 & 29.65 & 8.20 & 13.20 & 9,03 & 14.39 \\
\hline$\%$ wt to be loaded & 15.36 & 58.42 & 13.70 & 51.87 & 16,08 & 55.75 \\
\hline$\% \mathrm{wt}$ for a front-end fraction & $18.20^{1}$ & $29.65^{1}$ & $16.20^{2}$ & $26.08^{2}$ & $19.30^{3}$ & $30.75^{3}$ \\
\hline$\%$ wt for $\mathrm{WPhF}$ & 18.20 & 29.65 & 8.20 & 13.20 & 9.03 & 14.39 \\
\hline $\begin{array}{l}\text { 2. Water and unreacted components } \\
\mathrm{G}\end{array}$ & 100.25 & 21.10 & 51.65 & 12.25 & 47,15 & 11,42 \\
\hline$\%$ wt to be loaded & 84.64 & 41.58 & 86.30 & 48.13 & 83.92 & 44.25 \\
\hline$\% \mathrm{wt}$ for a front-end fraction & $100.25^{1}$ & $2.10^{1}$ & $102.08^{2}$ & $24.20^{2}$ & $100.75^{3}$ & $24.40^{3}$ \\
\hline$\%$ wt for $\mathrm{WPhF}$ & 100.25 & 21.10 & 51.65 & 12.25 & 47.15 & 11.42 \\
\hline Total, g & 118.45 & 50.75 & 59.85 & 25.44 & 56.18 & 25.81 \\
\hline
\end{tabular}

${ }^{1}$ for the wide phenolic fraction $(\mathrm{WPhF})$

${ }^{2}$ for the fraction IBP $-185^{\circ} \mathrm{C}$

${ }^{3}$ for the fraction $185-\mathrm{EBP}{ }^{\circ} \mathrm{C}$

When the concentrated phenols (raw phenols) are used in the act of synthesis, the yield is observed to be higher while loading the reactor (almost fourfold increase: $51.9-58.4 \% \mathrm{wt}$ against $13.7-16.1 \% \mathrm{wt}$ ) and for the initial fraction (nearly 2 times higher: $26.1-30.8 \% \mathrm{wt}$ against $16.2-$ $18.2 \% \mathrm{wt}$ ). So, for the obtaining of effective modifiers of petroleum bitumens, it is mostly appropriate to carry out the synthesis not with the use of the coal tar phenolic fraction but with the raw phenols being separated from this tar.

Additionally, it is counterproductive to break up the WPhF with two narrower factions. This is explained by that using RPh1 as the starting material produces $29.65 \%$ of the resin yield (calculated per $\mathrm{WPhF}$ ) whereas the total resin yield if two raw phenols $-\mathrm{RPh} 2$ and $\mathrm{RPh} 3-$ are used appears to be lower: $13.20+14.39=27.59 \%$.

From then on, in order to specify a temperature for bitumen modification, the BD 60/90 residual bitumen was modified with PhCR-F3 and PhCR-F4 resins derived directly from IBP $185^{\circ} \mathrm{C}$ and $\mathrm{RPh} 2$ raw phenol, respectively, at $110{ }^{\circ} \mathrm{C}$ and $190{ }^{\circ} \mathrm{C}$ temperatures. It can be stated that mechanical mixing of bitumen components occurs at $110^{\circ} \mathrm{C}$ while at $190{ }^{\circ} \mathrm{C}$ physical and chemical interactions between them are likely to be. Characteristics of bitumen-polymer blends obtained are given in Table 13. 
Table 13

Preparation conditions and main characteristics of obtained PMBs

\begin{tabular}{|c|c|c|c|c|c|}
\hline \multirow{3}{*}{ Index } & \multirow{3}{*}{ BD 60/90 } & \multicolumn{4}{|c|}{$\begin{array}{c}\text { Modification temperature, }{ }^{\circ} \mathrm{C} \\
\text { (modifier content in PMB }-2.4 \% \mathrm{wt} \text { ) }\end{array}$} \\
\hline & & \multicolumn{2}{|c|}{ PhCR-F3 } & \multicolumn{2}{|c|}{ PhCR-F4 } \\
\hline & & 110 & 190 & 110 & 190 \\
\hline Penetration at $25^{\circ} \mathrm{C}\left(\mathrm{m} \times 10^{-4}\right)$ & 80 & 78 & 75 & - & 62 \\
\hline Penetration decline, $\%$ & - & 2.5 & 6.3 & - & 22.5 \\
\hline $\begin{array}{l}\text { Softening point (ball \& } \\
\text { ring method) }\left({ }^{\circ} \mathrm{C}\right)\end{array}$ & 43 & 44 & 46 & - & 47 \\
\hline Softening point increase, $\%$ & - & 2.3 & 7.0 & - & 9.3 \\
\hline Ductility at $25^{\circ} \mathrm{C}\left(\mathrm{m} \times 10^{-2}\right)$ & $>100$ & $>100$ & $>100$ & - & $>100$ \\
\hline Adhesion to glass (\%) & 60 & 83 & 82 & - & 88 \\
\hline $\begin{array}{l}\text { Increase in adhesion to } \\
\text { glass, \% }\end{array}$ & - & 38.3 & 36.7 & - & 46.7 \\
\hline Homogeneity & $\begin{array}{c}\text { non } \\
\text { standardized }\end{array}$ & homogeneous & homogeneous & $\begin{array}{c}\text { not } \\
\text { homogeneous }\end{array}$ & homogeneous \\
\hline
\end{tabular}

Based on the data of Table 13, it can be suggested that the addition of synthesized PhCR-F3 and PhCR-F4 (except for the case of $110^{\circ} \mathrm{C}$ and PhCR-F4) into bitumen leads to an increase in the softening point and, especially, in the adhesion of residual petroleum bitumen. The modification of petroleum bitumen with PhCR-F3 can be done at both $110{ }^{\circ} \mathrm{C}$ and $190{ }^{\circ} \mathrm{C}$. In comparison, with PhCR-F4 - at $190{ }^{\circ} \mathrm{C}$ as $110^{\circ} \mathrm{C}$ produces modified bitumen that does not meet requirements of homogeneity. Mixing at $190{ }^{\circ} \mathrm{C}$ makes it possible to increase the softening point to a greater extent. It follows from mentioned above that further modification of petroleum-based bitumens with phenol-cresol-formaldehyde resins that were obtained from the coal tar phenolic fraction was decided to be made at $190^{\circ} \mathrm{C}$.

A comparison of main characteristics of obtained bitumen-polymer blends is shown in Table 14.

Table 14

Preparation conditions and main characteristics of obtained PMBs

\begin{tabular}{|c|c|c|c|c|c|c|c|}
\hline \multirow{2}{*}{ Index } & \multirow{2}{*}{ BD $60 / 90$} & \multicolumn{6}{|c|}{ Modified bitumen at $190^{\circ} \mathrm{C}$ (modifier content in PMB $-2.4 \%$ wt) } \\
\hline & & PhCR-F1 & PhCR-F2 & PhCR-F3 & PhCR-F4 & PhCR-F5 & PhCR-F6 \\
\hline 1 & 2 & 3 & 4 & 5 & 6 & 7 & 8 \\
\hline $\begin{array}{l}\text { Penetration at } 25^{\circ} \mathrm{C} \\
\left(\mathrm{m} \times 10^{-4}\right)\end{array}$ & 80 & 75 & 65 & 75 & 62 & 74 & 70 \\
\hline $\begin{array}{l}\text { Penetration decline, } \\
\%\end{array}$ & - & 6.3 & 18.8 & 6.3 & 22.5 & 7.5 & 12.5 \\
\hline $\mid$\begin{tabular}{ll}
\multicolumn{3}{l}{ Softening point } \\
$($ ball \& $\quad$ ring \\
method) $\left({ }^{\circ} \mathrm{C}\right)$
\end{tabular} & 43 & 44 & 46 & 46 & 47 & 45 & 46 \\
\hline $\begin{array}{l}\text { Softening } \\
\text { increase, } \%\end{array}$ & - & 2.3 & 7.0 & 7.0 & 9.3 & 4.7 & 7.0 \\
\hline $\begin{array}{l}\text { Ductility at } 25^{\circ} \mathrm{C} \\
(\mathrm{m} \times 10-2)\end{array}$ & $>100$ & $>100$ & $>100$ & $>100$ & $>100$ & $>100$ & $>100$ \\
\hline $\begin{array}{l}\text { Adhesion to glass } \\
(\%)\end{array}$ & 60 & 87 & 94 & 82 & 88 & 95 & 96 \\
\hline
\end{tabular}


Table 14 continue

\begin{tabular}{|c|c|c|c|c|c|c|c|}
\hline \multirow{2}{*}{ Index } & \multirow{2}{*}{ BD $60 / 90$} & \multicolumn{6}{|c|}{ Modified bitumen at $190^{\circ} \mathrm{C}$ (modifier content in PMB $-2.4 \% \mathrm{wt}$ ) } \\
\hline & & PhCR-F1 & PhCR-F2 & PhCR-F3 & PhCR-F4 & PhCR-F5 & PhCR-F6 \\
\hline 1 & 2 & 3 & 4 & 5 & 6 & 7 & 8 \\
\hline $\begin{array}{l}\text { Increase in adhesion } \\
\text { to glass, } \%\end{array}$ & - & 45.0 & 56.7 & 36.7 & 46.7 & 58.3 & 60.0 \\
\hline Homogeneity & $\begin{array}{c}\text { non } \\
\text { standardized }\end{array}$ & $\begin{array}{l}\text { homo- } \\
\text { geneous }\end{array}$ & $\begin{array}{l}\text { homo- } \\
\text { geneous }\end{array}$ & $\begin{array}{l}\text { homo- } \\
\text { geneous }\end{array}$ & $\begin{array}{l}\text { homo- } \\
\text { geneous }\end{array}$ & $\begin{array}{l}\text { homo- } \\
\text { geneous }\end{array}$ & $\begin{array}{l}\text { homo- } \\
\text { geneous }\end{array}$ \\
\hline
\end{tabular}

Table 14 shows that adding all the obtained resins essentially improves the adhesive properties of bitumen. The data outlined in Table 14 indicate that the addition of the BD 60/90 resins synthesized from raw phenol (PhCR-F2, PhCR-F4 and PhCR-F6) gives rise to a larger increase in the softening point and adhesion compared to the ones synthesized from the WPhF, fraction IBP - 185, $185-\mathrm{EBP}{ }^{\circ} \mathrm{C}$ (PhCR-F1, PhCR-F3 and PhCR-F5), but more increasingly reduces the plasticity (penetration) of the BD 60/90 residual bitumen.

With an increased content of cresols in the starting material (PhCR-F5 and PhCR-F6) compared to PhCR-F3 and PhCR-F4, the obtained modified bitumen possesses better adhesive properties (95-96\% against 82- 88\%, see Table 14). Nevertheless, the use of raw phenols produced from the WPhF allows almost the same adhesive properties to be obtained and the softening point to be raised as when PhCR-F5 and PhCR-F6 are used.

Consequently, this results in:

- higher yield of resin if raw phenols are used for its synthesis;

- slightly better characteristics of resin-modified bitumens, which contain more cresols

(PhCR-F2, PhCR-F5 and PhCR-F6);

- lack of appropriateness to break up the WPhF with two narrow fractions.

- distilled road bitumens should be preferably modified with PhCR-F2.

To confirm the possibility of modifying the resulting resins as well as the oxidized bitumens coupled with the ability to compare the effectiveness of modifying the oxidized and residual bitumens, Table 15 shows the main characteristics of these PhCR-F2 modified bitumens.

Table 15

Comparison of main characteristics between residual and oxidized PhCR-F2 modified bitumens

\begin{tabular}{|c|c|c|c|c|}
\hline Index & BD 60/90 & $\begin{array}{c}\text { BD } 60 / 90+\text { PhCR- } \\
\text { F2 }(2,4 \% \mathrm{wt}) \\
\end{array}$ & BND 60/90 & $\begin{array}{c}\text { BND } 60 / 90+\text { PhCR- } \\
\text { F2 }(2,4 \% \mathrm{wt})\end{array}$ \\
\hline Penetration at $25^{\circ} \mathrm{C}\left(\mathrm{m} \times 10^{-4}\right)$ & 80 & 65 & 70 & 60 \\
\hline Penetration decline, $\%$ & - & 18.8 & - & 14.3 \\
\hline $\begin{array}{l}\text { Softening point } \\
\text { (ball \& ring method) }\left({ }^{\circ} \mathrm{C}\right)\end{array}$ & 43 & 46 & 46 & 49 \\
\hline Softening point increase, $\%$ & - & 7.0 & - & 6.5 \\
\hline Ductility at $25^{\circ} \mathrm{C}\left(\mathrm{m} \times 10^{-2}\right)$ & $>100$ & $>100$ & 63 & 25 \\
\hline Adhesion to glass (\%) & 60 & 94 & 47 & 97 \\
\hline $\begin{array}{l}\text { Increase in adhesion to glass, } \\
\%\end{array}$ & - & 56.7 & - & 106.4 \\
\hline Homogeneity & $\begin{array}{c}\text { non } \\
\text { standardized }\end{array}$ & homogeneous & $\begin{array}{c}\text { non } \\
\text { standardized }\end{array}$ & homogeneous \\
\hline
\end{tabular}


Supported by data given in Table 9, it may be argued that the modification with PhCR-F2 resin raises the softening point of both distilled and oxidized road bitumens by $3{ }^{\circ} \mathrm{C}$. For the distilled bitumen, the adhesive properties of PMBs are increased by $56.7 \%$ (from 60 to $94 \%$ ), while the oxidized one exhibits an increase of $106.4 \%$ (from 47 to $97 \%$ ). This indicates that the resin obtained can also be utilized as adhesive additives in particular for the oxidized bitumens.

Conclusions. $85 \%$ of bitumen production (on the average about $90 \mathrm{mln}$.tons of bitumen per year) is used as a binder in road construction. However oxidized and residual bitumen does not have the necessary properties to meet modern requirements to the pavement.The most common way to increase the performance properties of oil bitumen (primarily, oxidized bitumen) is the use of various polymers as modifiers. Polymer modified bitumen compared to conventional bitumen has a number of significant advantages. They are more elastic, flexible and durable, less sensitive to the temperature changes and aging, have better adhesive and cohesive properties.But the main reason that restrains thermoplastic elastomers prevalence is their high cost. An effective solution of this problem is their partial or complete replacement by cheaper polymers.

A promising direction is the production of modifiers from by-products of fossil fuels thermodestruction, which contain a sufficiently large amount of unsaturated compounds. The latter one can be used to produce modified bitumen, which meets regulatory requirements and has extremely high adhesion (till $100 \%$ ).

Using coumarone-indene resin as the modifier of road bitumen increases the softeningpoints from 47 to $52{ }^{\circ} \mathrm{C}$ and improves adhesive properties (adhesion to glass increases from 38 to $93 \%$ ) but degrades plastic properties (especially penetration). Therefore to solve this problem it is necessary to use the plasticizer together with the modifier. It is recommended to use tar as the plasticizer. The commercial polymers modified bitumen 60/90-52 bitumen was obtained as a result of mixing road bitumen of BND 60/90 brand (85 wt. \%), CIR (7 wt. \%) and tar from WestUkrainian oils ( 8 wt. \%) at $110^{\circ} \mathrm{C}$.

Novolac phenol-cresol-formaldehyde resins were produced by the method of formaldehyde condensation polymerization and from the wide phenolic fraction, fraction IBP - 185 and $185-$ EBP ${ }^{\circ} \mathrm{C}$ and from the raw phenols extracted from these fractions. The results achieved show that the use of raw phenols as the starting material is the most advisable for the synthesis of resins as this allows the resin yield to be increased nearly fourfold while loading the reactor (from 13.7$16.1 \% \mathrm{wt}$ to $51.9-58.4 \% \mathrm{wt}$, respectively).

Modification of petroleum-derived road bitumens should be performed with phenol-cresolformaldehyde resin that was obtained from raw phenols, extracted from the wide phenolic fraction of coal tar. It is counterproductive for the obtaining of resin to break up the wide phenolic fraction with phenol concentrate (fraction IBP $-185^{\circ} \mathrm{C}$ ) and concentrate of cresols $\left(185-\mathrm{EBP}{ }^{\circ} \mathrm{C}\right.$ ). It has been observed that with a content of $2.4 \%$ by weight of phenol-cresol-formaldehyde resins in distilled (residual) and oxidized petroleum-derived road bitumens, there is an increase of $3{ }^{\circ} \mathrm{C}$ in the softening point and adhesive properties for the distilled bitumenby $56.7 \%$ (from 60 to $94 \%$ ), for the oxidized one - by 106, $4 \%$ (from 47 to $97 \%$ ).

\section{PЕФЕРАТ}

Сергій Пиш'єв, Володимир Гунька, Юрій Присяжний

\section{Національний університет «Львівська політехніка», volodymyr.m.hunka@lpпи.иа}

\section{БІТУМИ, МОДИФІКОВАНІ ПОЛІМЕРАМИ}

У статті розглянуто основні способи модифікації бітумів полімерами. Встановлено, що використання полімерних модифікаторів дає змогу покращити експлуатаційні властивості бітумів. Проаналізовано позитивні і негативні аспекти використання різних груп полімерних модифікаторів (еластомери, термоеластопласти, реактопласти, термопласти). Показано досягнення кафедри хімічної технології переробки нафти та газу Національного університету «Львівська політехніка» в галузі модифікації бітумів полімерами: інден-кумароновою, нафтополімерними, фенол формальдегідними і епоксидними смолами. 
Ключові слова: бітуми, модифіковані полімерами, еластомери, термоеластопласти, реактопласти, термопласти, інден-кумаронові смоли, фенолформальдегідні смоли.

\section{PЕФЕРАТ \\ Сергей Пишьев, Владимир Гунька, Юрий Присяжный \\ Наииональный университет «Львовская политехника»,volodymyr.m.hunka@lpnu.иa}

БИТУМЫ, МОДИФИЦИРОВАННЫЕ ПОЛИМЕРАМИ

В статье рассмотрены основные способы модификации битумов полимерами. Установлено, что использование полимерных модификаторов позволяет улучшить эксплуатационные свойства битумов. Проанализированы положительные и отрицательные аспектыиспользования различных групп полимерных модификаторов (эластомеры, термоэластопласты, реактопласты, термопласты). Показано достижения кафедры химической технологии переработки нефти и газа Национального университета «Львовская политехника» в области модификации битумов полимерами: инден-кумароновой, нефтеполимерной, фенолформальдегидной и эпоксидной смолами.

Ключевые слова: битумы, модифицированные полимерами, эластомеры, термоэластопласты, реактопласты, термопласты, инден-кумароновые смолы, фенолформальдегидные смолы.

\section{ABSTRACT \\ Serhiy Pyshyev, Volodymyr Gunka, Yuriy Prysiazhnyi \\ National University “Lviv Polytechnic”, volodymyr.m.hunka@lpnu.ua}

\section{POLYMER MODIFIED BITUMEN}

The reasons for bitumen modification were analysed since bitumen is a main binder used at road coatings construction, including airports and airdromes. The main ways of bitumen modification by polymers were examined. Positive and negative aspects of the usage of different polymer modifiers (elastomers, thermoplastic elastomers, reactive polymers, thermoplastics) were analysed. Author's main achievements are described in the sphere of bitumen modification by polymeric compounds produced at by-product-coke plants: coumarone-indene and phenol-cresol-formaldehyde resins.

Key words: polymer modified bitumen, elastomer, thermoplastic elastomer, reactive polymer, thermoplastic, coumarone-indene resin, phenol formaldehyde resin.

\section{REFERENCES}

1. Bitumen asphalt, total productin - for all countries [Electronic reference]. - Access mode:

http://www.factfish.com/statistic/bitumen\%20asphalt,\%20total\%20productin.

2. Bitumen asphalt, exports (thousand metric tons) - for all countries [Electronic reference]. - Access mode: http://www.factfish.com/statistic/bitumen $\% 20$ asphalt $\% 2 \mathrm{C} \% 20$ exports.

3. Bitumen asphalt, imports (thousand metric tons) - for all countries [Electronic reference]. - Access mode: http://www.factfish.com/statistic/bitumen\%20asphalt $\% 2 \mathrm{C} \% 20$ imports.

4. Galdina V. Modified bitumen: a tutorial/V. Galdina. - Omsk: SibADI, 2009. - 228 pp.

5. Kishchinsky S.V. Physical and mechanical properties of bitumen, modified by a complex modifier Polyd / S.V. Kishchinsky // Vestn. HNADU. - 2008. - Issue 40. - P. 28-32.

6. Zhu Jiqing. Polymer modification of bitumen: Advances and challenges / Jiqing Zhu, Björn Birgisson, Niki Kringos // European Polymer Journal. - 2014. - Vol. 54. - P. 18-38.

7. Tarasov R.V. Modification of bitumens by polymers / R.V. Tarasov, L.V. Makarova, A.A. Kadomtseva// Modern scientific researches and innovations [Electronic reference]. - 2014. - № 5. - Access mode:

http://web.snauka.ru/en/issues/2014/05/34687.

8. Valentová T. Impact of Asphalt Ageing on the Activity of Adhesion Promoters and the Moisture Susceptibility / Tereza Valentová, Jan Altman, Jan Valentin // Transportation Research Procedia. - 2016. - Vol. 14. - P. 768-777.

9. Impact of Ageing and the Stability of Adhesion Additive on Moisture Susceptibility and Adhesion / [Hamidi Abdul Aziz, Meor Othman Hamzah, Fauziah Ahmad et al.]. // Applied echanics and Materials. - 2015. - Vol. 802. - P. 309-314.

10. Plasticizing additives from phthalic anhydride residue and 2-ethylhexanol residue for improvement of properties of road petroleum bitumens / G.N. Kinzyagulova, A.S. Alyabev, N.G. Evdokimova, I.A. Sultanbekova // Electronic scientific journal «Oil and Gas Business» [Electronic reference]. - 2009. - №1. - Access mode: http://ogbus.ru/eng/authors/Kinzyagulova/Kinzyagulova_1.pdf. 
11. Mousavi S.M. Enhancement of rheological and mechanical properties of bitumen using styrene acrylonitrile copolymer / Seyed Mojtaba Mousavi, Mohammad Farsi, Mahdi Azizi // Journal of Applied Polymer Science. - 2015. - Vol. 132 (17). - P. 41875.

12. Petroleum Bitumen Modified by Polymer Materials for Asphalt Concrete Surfacing with Improved Operational Performance / P. S. Belyaev, D. L. Polushkin, P. V. Makeev, V. A. Frolov // Transactions TSTU. - 2016. - Vol. 22 (2). - P. 264.

13. Muneraa J.C. Polymer modified bitumen: Optimization and selection / J.C. Muneraa, E.A. Ossa // Materials and Design. - 2016. - Vol. 62. - P. 91-97.

14. Package of polyfunctional modifiers (pfm) for production of bitumen and bitumen materials of wide assortment with high operational properties [Electronic reference] - Access mode: http://www.econf.rae.ru/article/4548.

15. BulatovićV.O. Effect of polymer modifiers on the properties of bitumen / Vesna Ocelic'Bulatovic', Vesna Rek and Kristina Jurkas`Markovic // Journal of Elastomers and Plastics. - 2014. - Vol. 46. - P. 448-469.

16. Vasavi S. Efect of natural rubber on the properties of bitumen and bituminous mixes / S. Vasavi, D. Rani // International Journal of Civil Engineering and Technology. - 2014. - Vol. 5 (10). - P. 9-21.

17. Keyf $S$. The modification of bitumen with reactive ethylene terpolymer, styrene butadiene styrene and variable amounts of ethylene vinyl acetate / S. Keyf // Research on Chemical Intermediates. - 2015. - Vol. 41 (3). - P. 1485-1497.

18. Vichitcholchai N. Modification of Asphalt Cement by Natural Rubber for Pavement Construction / Nopparat Vichitcholchai, Jaratsri Panmai and Nuchanat Na-Ranong // Rubber thai journal. - 2012. - Vol. 1. P. 32-39.

19. Review on the Effect of Crumb Rubber Addition to the Rheology of Crumb Rubber Modified Bitumen / [Mohd Rasdan Ibrahim, Herda Yati Katman, Mohamed Rehan Karim et al.]. // Advances in Materials Science and Engineering. - 2013. - Vol. 2013. - Article ID 415246.

20. Review on Using Crumb Rubber in Reinforcement of Asphalt Pavement / Nuha Salim Mashaan, Asim Hassan Ali, Mohamed Rehan Karim, Mahrez Abdelaziz // Scientific World Journal. - 2014. - Vol. 2014. - P. 214612.

21. A study of crumb rubber modified bitumen used in South Africa / Georges A.J. Mturi, Johan O'Connell, Salah E. Zoorob, Morris De Beer // Road Materials and Pavement Design. - 2014. - Vol. 15 (4). - P. 774 790.

22. Polymer modified bitumen: Rheological properties and structural characterization / [Cesare Oliviero Rossi, Assunta Spadafora, Bagdat Teltayev et al.]. // Colloids and Surfaces A Physicochemical and Engineering Aspects. - 2015. - Vol. 480. - P. 390-397.

23. Effect of styrene-butadiene-styrene copolymer modification on properties of Saudi bitumen / Abdulrahman A. Al-Rabiah, Omar Y. Abdelaziz, Enrique M. Montero, Mohamed S. Aazam // Petroleum Science and Technology. - 2016. - Vol. 34 (4). - P. 321-327.

24. Choice of polymer-bitumen binders for cast asphalt concrete mixes / S. V. Vorontsov, N. V. Maidanova, A. M. Syroezhko, S. N. Ivanov // Russian Journal of Applied Chemistry. - 2012. -Vol. 85 (2) - P. 323-330.

25. Karton [Electronic reference]. - Access mode: http://www.kraton.com.

26. Total [Electronic reference]. - Access mode: http://www.total.com/en.

27. Eni [Electronic reference]. - Access mode: https://www.eni.com/en_IT/products.page.

28. Dynasol group [Electronic reference]. - Access mode: http://www.dynasolelastomers.com.

29. Modified Phenol-Formaldehyde Resins and their Application in Bitumen-Polymeric Mixtures / [Galyna Strap, Olena Astakhova, Olexander Lazorko et al.]. // Chemistry \& Chemical Technology. - 2013. - Vol. 7 (3). - P. 279-287.

30. Rheological Properties and Performance Evaluation of Phenol Formaldehyde Modified Bitumen / M.Çubuk, M.Gürü, M. Çubuk, D. Arslan // Journal of Materials in Civil Engineering. - 2014. - Vol. 26 (6). - P. 04014015.

31. Abd El Rahman A. Modification of local asphalt with epoxy resin to be used in pavement / A.M.M. Abd El Rahman, M. EL-Shafie, S.A. El Kholy // Egyptian Journal of Petroleum. - 2012. - Vol. 21 (2). - P. 139147.

32. Ivashkiv O. Structure and Application of ED-20 Epoxy Resin Hydroxy-Containing Derivatives in Bitumen-Polymeric Blends / [O. Ivashkiv, O. Astakhova, O. Shyshchak et al.]. // Chemistry \& Chemical Technology. - 2015. - Vol. 9. - № 1. - P. 69-76.

33. Monomethacrylate derivative of ED-24 epoxy resin and its application / [Oksana Iatsyshyn, Olena Astakhova, Olena Shyshchak et al.]. // Egyptian Journal of Petroleum. - 2013. - Vol. 7 (1). - P. 73-77. 
34. Binder Design for Asphalt Mixes with Reduced Temperature: EVA Modified Bitumen and its Emulsions / Avido Yuliestyan, Antonio Abad Cuadri, Moisés García-Morales, Pedro Partal // Transportation Research Procedia. - 2016. - Vol. 14. - P. 3512-3518.

35. Bulatovic $V$. Rheological properties and stability of ethylenevinylacetatepolymer-modified bitumen / Vesna Ocelić Bulatović, VesnaRek, KristinaJurkaš Marković // Polymer Engineering \& Science. - 2013. - Vol. 53 (11). - P. 2276-2283.

36. Brozyna D. Modification of asphalt binders by polyethylene-type polymers / Dariusz Brożyna, Karol J. Kowalskia // Journal of Building Chemistry. - 2016. - Vol. 1. - P. 37-41.

37. Rheological Properties of Polyethylene and Polypropylene Modified Bitumen / Noor Zainab Habib, Ibrahim Kamaruddin, Madzalan Napiah, Isa Mohd Tan // International Journal of Civil, Environmental, Structural, Construction and Architectural Engineering. - 2010. - Vol. 4 (12). - P. 381-385.

38. Al-Ameri M. Modification of Residual Bitumen from orhovytska Oil by Butonal Polymeric Latexes / Mohammad Al-Ameri, Oleh Grynyshyn and Yuriy Khlibyshyn // Chemistry \& Chemical Technology. - 2013. - Vol. 7 (3). - P. 323-326.

39. Onischenko A. Research on Properties of Bitumen Modified with Polymers Used for Asphalt Concrete Pavement on Bridges / Arthur Onischenko, Mykolay Kuzminets, Sergey Aksenov // Teka. Commission of motorization and energetics in agriculture. - 2014. - Vol. 14 (4). - P. 113-118.

40. Research of influencing of parameters of preparation of the bitumen modified by polymeric latex of butonal ns 104, on property of travelling bitumen / V.Mozgovoy, A.Besarab, A.Prudkiy, V. Smolianets // Bulletin of Kharkov National Automobile and Highway University. - 2006. - Vol. 34-35.

41. Basf [Electronic reference]. - Access mode: https://www.basf.com.

42. Dupont [Electronic reference]. - Access mode: http://www.dupont.com.

43. Petroleum resins for bitumens modification / Oleg Grynyshyn, Michael Bratychak, Volodymyr Krynytskiy, Volodymyr Donchak. // Chemistry \& ChemicalTechnology. - 2008. - Vol. 2 (1) . - P. 47-53.

44. Grynyshyn O. Production of Bitumen Modified by Petroleum Resins on the Basis of Tars of Ukrainian Oils / Oleg Grynyshyn, Olena Astakhova, Taras Chervinskyy // Chemistry \& Chemical Technology. - 2010. - Vol. 4 (3). - P. 241-246.

45. Functional petroleum resins based on pyrolysis by-products and their application for bitumen modification / [M. Bratychak, O. Grynyshyn, O. Astakhova et al.]. // Ecological Chemistry and Engineering. - 2010. - Vol. 17 (3). - P. 309-315.

46. Production of Indene-coumarone Resins as Bitumen Modifiers / [Serhiy Pyshyev, Yuriy Grytsenko, Nazar Danyliv et al.]. // Petroleum \& Coal. - 2015. - Vol. 57. - Issue 4. - P. 303.

47. Using bitumen emulsions based on oxidated, distillation and modified oxidated bitumens for Slurry Seal production / [Serhiy Pyshyev, Yuriy Grytsenko, Serhiy Solodkyy et al.]. // Chemistry \& Chemical Technology. - 2015. - Vol. 9 (3). - P. 359-366.

48. The production of indene-coumarone resins for modification of oil road-bitumen / S.V. Pyshyev, Yu.B. Gritsenko, I.Ye. Nykulyshyn, Z. Ya. Gnativ // Journal of Coal Chemistry. - 2014. - № 5-6. - P. 41-48.

49. Demchuk Y. Obtaining of the modifiers of road bitumen from phenol fraction of coal tar / Y. Demchuk, V. Gunka, S. Pyshyev, M. Bratychak // Uglekhim. Zh. - 2017. - №5. - P.2 3-28.

50. Effect of Phenol-Cresol-Formaldehyde Resin on Adhesive and Physico-Mechanical Properties of Road Bitumen / [Y. Demchuk, Iu. Sidun, V. Gunka et al.]. // Chemistry \& Chemical Technology. - 2018. - Vol. 12 (4). - P. 456.

51. Production of Indene-coumarone Resins as Bitumen Modifiers / [S.Pyshyev, Y.Grytsenko, H.Bilushchak et al.]. // Petroleum and Coal. - 2015. - №4. - P. 303-314.

52. The production of indene-koumarone resins for modification of oil road-bitumen / S.V.Pyshyev, Y.B.Gritsenko, I.Y.Nykulyshyn, Z.Y. Gnativ // Journal of Coal Chemistry. - 2014 - - № 5-6. - P. 41-48.

53. D.V. Miroshnichenko. Predicting the yield of coke and its byproducts on the basis of elementary and petrographic analysisn / D.V.Miroshnichenko, M.B. Golovko // Coke and Chemistry. - 2014. - №3. - P. 3243.

54. Predicting the yield of coking byproducts on the basis of elementary and petrographic analysis of the coal batch / M.B. Golovko, I.D. Drozdnik, D.V. Miroshnichenko, Y.S. Kaftan // Coke and Chemistry. - 2014. - № 6. - P. 204-214.

55. Gunka $V$. Lignite oxidative desulphurization. Notice 2: effects of process parameters / Volodymyr Gunka, Serhiy Pyshyev // International Journal of Coal Science \& Technology.- 2015.- Vol. 2 (3). - P. 196-201.

56. Gunka V. Technology of Oxidative Desulphurization of Lignite / Volodymyr Gunka, Serhiy Pyshyev // Petroleum \& Coal. -2015. - Vol. 57. - Issue 6. - P. 696-704. 
57. Lignite oxidative desulphurization. Notice 1. Process condition selection / Volodymyr Gunka, Serhiy Pyshyev // International Journal of Coal Science \& Technology. - 2014. - Vol. 1. - Issue 1. - P. 62-69.

58. Toroptseva A.M. Laboratory session on chemistry and technology of high-molecular compounds / A.M. Toroptseva, K.M. Belogorodskaya, V.M. Bondarenko. - Chemistry: L., 1972. - P. 416.

DOI: doi.org/10.18372/38228

UDC: $519.23: 519.242$

\subsection{STATISTICAL METHODS IN VIRTUALIZATION}

\section{Alexandr Moiseev, Nikolay Grishin, Alexandr Oreshencov}

The basis for virtualization is virtualization tools, including families of base functional means and base mathematical models [1]. Functional means usually use for synthesis or simulation of the software of various purpose, including processing of results of qualifying tests [2]. Base models use for testing the software, synthesis of identification models for is modelling - the focused control systems, and also algorithms of processing of results of qualifying tests.

An important component of the virtualization toolkit (see Fig. 1) is a statistical component to solve the following problems: identifications of statistical models by results of qualifying tests, parametrization criteria models for carrying out of forecasting within the limits of virtual qualification, synthesis regression models, the statistical analysis of their adequacy and consecutive optimization during factorial planning. Regression model in structure of the toolkit, calibrated by results of qualifying tests, use for planning qualifying experiments. As a rule, this planning is based on use of the sated plans and gives following opportunities to:

- research the importance and completeness of system of the entered factors;

- carry out consecutive optimization of the parameters corresponding significant factors, during qualifying tests;

- carry out forecasting qualifying tests with use calibrated regression models.

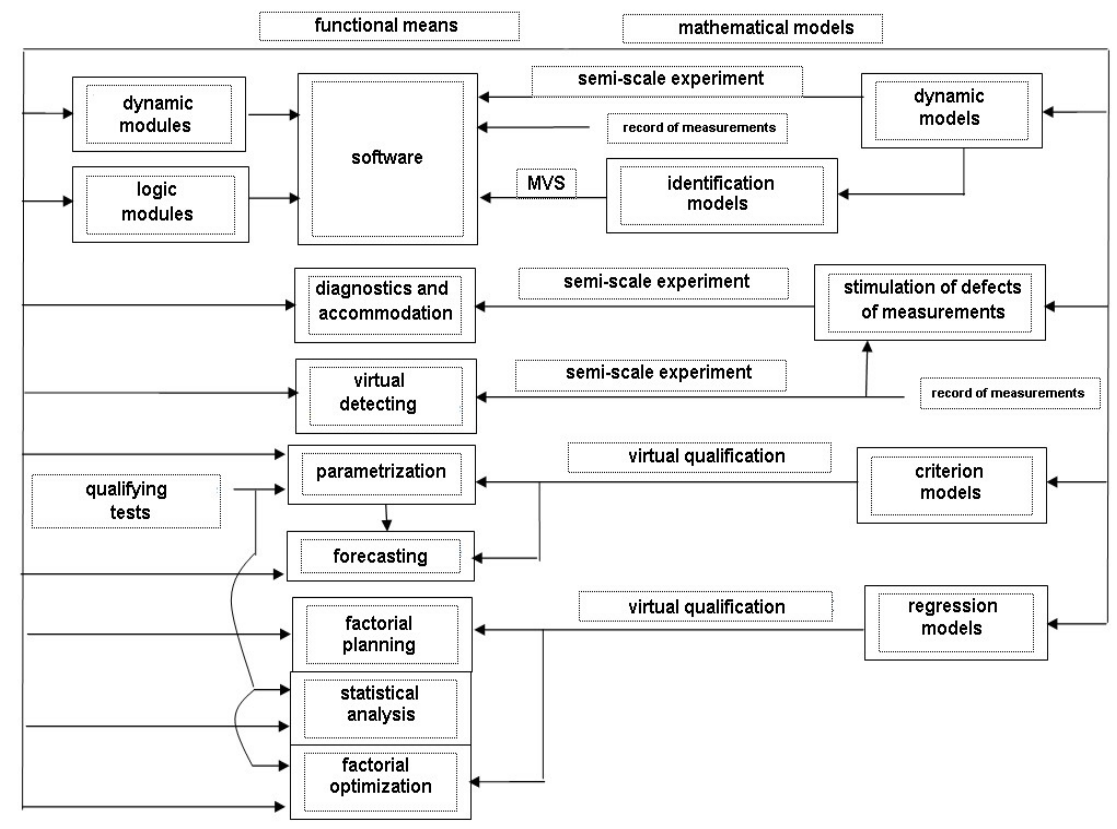

Fig. 1. Virtualization tools 